\title{
The Value-Extracting CEO: How Executive Stock-Based Pay Undermines Investment in Productive Capabilities
}

\author{
William Lazonick ${ }^{*}$
}

\section{Working Paper No. 54}

\author{
December 3, 2016
}

\begin{abstract}
The business corporation is the central economic institution in a modern economy. A company's senior executives, with the advice and support of the board of directors, are responsible for the allocation of corporate resources to investments in productive capabilities. Senior executives also advise the board on the extent to which, given the need to invest in productive capabilities, the company can afford to make cash distributions to shareholders. Motivating corporate resource-

William Lazonick is Professor of Economics, University of Massachusetts Lowell; President, The AcademicIndustry Research Network; Visiting Professor, University of Ljubljana; Distinguished Research Associate, Institut Mines-Télécom, Paris; Professorial Research Associate, SOAS University of London. (email:

william.lazonick@gmail.com).

This paper reflects research being carried out under grants from the Institute for New Economic Thinking (Collective and Cumulative Careers project through the Academic-Industry Research Network) and the European Commission (Innovation-Fuelled Sustainable and Inclusive Growth through the University of Ljubljana). It also builds on research done on previous grants from the Institute for New Economic Thinking and from the Ford Foundation (Financial Institutions for Innovation and Development through UMass Lowell). Some of the material in this paper draws on Matt Hopkins and William Lazonick, "The Mismeasure of Mammon," Uses and Abuses of Executive Pay Data," Institute for New Economic Thinking Working Paper No. 49, August 29, 2016, at https://www.ineteconomics.org/ideas-papers/research-papers/the-mismeasure-of-mammon-uses-and-abuses-ofexecutive-pay-data
\end{abstract}


allocation decisions are the modes of remuneration that incentivize and reward the top executives of these companies. A sound analysis of the operation and performance of a modern economy requires an understanding of not only how much these executives are paid but also the ways in which the prevailing system of executive pay influences their decisions to allocate corporate resources. In the United States since the last half of the 1980s the overriding goal of U.S. corporations has been to "maximize shareholder value," with corporate performance measured by a company's "total shareholder return": percentage stock-price appreciation plus dividend yield. Also since the $1980 \mathrm{~s}$, the most important components of the total compensation of senior executives have been modes of stock-based pay in the forms of stock options and stock awards. This stock-based pay is structured to incentivize executives to make corporate allocation decisions that will boost the stock prices of the companies that employ them and reward them for achieving that objective. There are three drivers of stock prices: innovation, speculation, and manipulation. The first critical question that this paper addresses is which of these drivers, individually or in combination, contribute to a company's stock-price performance. Then we can ask the second critical question: Does executive compensation reflect the success of the company in value creation, or the power of senior executives to engage in value extraction? The "valueextracting CEO" hypothesis posits that, in the United States, a significant portion of senior executive compensation rewards them for making decisions that foment speculation and manipulate stock prices, and thereby extract value for their own personal gain. In section four of the paper, I invoke the theory of innovative enterprise to support this hypothesis and debunk the dominant ideology that companies should be run to "maximize shareholder value." Finally, I elaborate the policy implications for controlling the power of the value-extracting CEO, including a) banning stock buybacks, b) requiring executive compensation that rewards innovation rather than speculation and manipulation, and c) placing stakeholders representing households as taxpayers, workers, and consumers on boards of directors of publicly listed companies, along with shareholders who represent households as savers. An intellectual precondition for these reforms is the rejection of the ideology that companies should be run to maximize shareholder value, which means replacing agency theory with innovation theory as a mode of analyzing how the operation of an economy, supported by the strategies and structures of the business enterprises within it, can attain the objectives of stable and equitable economic growth.

\section{JEL Codes: D01, D21, D31, G35, J33}

Keywords: Corporation, senior executive, stock-based compensation, stock prices, stock buybacks, innovation, speculation, manipulation, innovation theory, agency theory, shareholdervalue ideology 


\section{Corporate Resource Allocation and Productive Capabilities}

The business corporation is the central economic institution in a modern economy. In the U.S. economy, as a prime example, employment, productivity and earnings depend heavily on resource-allocation decisions made by the CEOs and their senior-management teams at a relatively small number of very large companies. ${ }^{1}$ In $2012,1,909$ companies that had 5,000 or more employees in the United States, with an average workforce of 20,366, were only 0.033 percent of all U.S. businesses. But, with the business sector representing 81 percent of the total employed civilian labor force, these 1,909 companies had 11 percent of all establishments, 34 percent of employees, 38 percent of payrolls, and 44 percent of revenues. $^{2}$ In addition, the prosperity of hundreds of thousands of smaller firms relies on the growth of these large firms.

A company's senior executives, with the advice and support of the board of directors, are responsible for the allocation of corporate resources to investments in productive capabilities. Senior executives also advise the board on the extent to which, given the need to invest in productive capabilities, the company can afford to make cash distributions to shareholders. Motivating corporate resource-allocation decisions are the modes of remuneration that incentivize and reward the top executives of these companies. CEOs may also be motivated by non-pecuniary objectives in making resource-allocation decisions. But a sound analysis of the operation and performance of the U.S. economy-or any modern economy-requires an understanding of not only how much these executives are paid but also the ways in which the prevailing system of executive pay influences their decisions to allocate corporate resources.

Modes of compensation, characterized by an array of different pay components, ostensibly incentivize senior executives to behave in ways that improve corporate performance and reward them for achieving performance goals. But what is the measure of superior corporate performance that incentivizes and rewards them? In the United States since the last half of the 1980s the overriding goal of U.S. corporations has been to "maximize shareholder value" (MSV), with corporate performance measured by a company's "total shareholder return": percentage stock-price appreciation plus dividend yield. Also since the 1980s, the most important components of the total compensation of senior executives have been modes of stock-based pay in the forms of stock options and stock awards. This stock-based pay is structured to incentivize executives to make corporate allocation

1 William Lazonick, "Labor in the Twenty-First Century: The Top 0.1\% and the Disappearing Middle Class," in Christian E. Weller, ed., Inequality, Uncertainty, and Opportunity: The Varied and Growing Role of Finance in Labor Relations, Cornell University Press, 2015: 143-192.

2 For 964 companies with 10,000 or more employees in 2012, these shares were nine percent of establishments, 28 percent of employees, 31 percent of payrolls, and 36 percent of revenues. United States Census Bureau, "Statistics of U.S. Businesses (SUSB)," Data on “2012 SUSB Annual Data Tables by Establishment Industry” at

https://www.census.gov/data/tables/2012/econ/susb/2012-susb-annual.html. The most recent data for 2014 (which do not include revenues) show that 1,986 firms with 5,000 or more employees and 994 firms with 10,000 or more employees had slightly larger shares of establishments, employees, and payrolls than the largest firms in 2012:

https://www.census.gov/data/tables/2014/econ/susb/2014-susb-annual.html 
decisions that will boost the stock prices of the companies that employ them and reward them for achieving this objective. ${ }^{3}$

Whether one admires or abhors the current system of executive compensation in the United States, there is a broad consensus that the achievement of a high and rising company stock price is the paramount corporate-performance objective. ${ }^{4}$ Does a rising stock price reflect superior corporate performance? Possibly, but by no means necessarily. As I discuss in the next section of the paper, there are three drivers of stock prices: innovation, speculation, and manipulation. Only "innovation" reflects superior economic performance, and the stock-market registers the impact of innovation only after it has occurred. The first critical question that this paper addresses is which of these drivers, individually or in combination, contribute to a company's stock-price performance.

Then we can ask the second critical question: Does executive compensation reflect the success of the company in value creation, or the power of senior executives to engage in value extraction? Based on intensive research into these questions for the U.S. case, my short answers are that a) the stock-price performance of major U.S. companies increasingly reflects manipulation, and b) given the preponderance of stock-based pay in the total compensation of the senior executives of major U.S. business corporations, their remuneration reflects their power to extract value far in excess of the value they help to create in the companies that they control.

Innovation is the process by which a company, embedded in a particular economic and political context, generates a product that is higher quality and lower cost than those products previously available. When a company invests in productive capabilities, it creates the possibility, although by no means the certainty, that through the development and utilization of its productive capabilities, it will be able to generate an innovative (higher-quality, lower-cost) product. As the innovative enterprise expands its extent of the market and becomes more profitable, stock-market traders will tend to bid up its stock price to reflect the gains from innovation that the company has already achieved.

At that point, stock-market speculation that future gains from innovation will occur can drive the company's price still higher. Under certain conditions, this speculation may continue at a rapid pace for an extended period of time, with the stock price propelled to new heights by speculative traders' adherence to the "greater fool theory": traders buy a company's shares at prices that they think are overvalued on the assumption that there remain greater fools in the market who will be willing to buy the shares at even higher prices. At some point, however, as increasing numbers of traders lose their speculative

\footnotetext{
3 See William Lazonick, "Taking Stock: How Executive Pay Results in an Inequitable and Unstable Economy," Franklin and Eleanor Roosevelt Institute White Paper, June 5, 2014, at

http://www.theairnet.org/v3/backbone/uploads/2014/08/Lazonick_Executive_Pay_White_Paper_Roosevelt_Institute. pdf; Matt Hopkins and William Lazonick, "The Mismeasure of Mammon: The Uses and Abuses of Executive Pay Data," Institute for New Economic Thinking Working Paper No. 49, at https://www.ineteconomics.org/research/researchpapers/the-mismeasure-of-mammon-uses-and-abuses-of-executive-pay-data.

4 For a critical recognition of this consensus (and the need to change it), see Joe Biden, "How short-termism saps the economy," Wall Street Journal, September 27, 2016, at http://www.wsj.com/articles/how-short-termism-saps-theeconomy-1475018087
} 
optimism, the greatest fools are left holding the overvalued shares, and the stock price declines, often precipitously, as they seek to cut their losses.

Hence, as we observe in practice, stock prices can go through highly volatile booms and busts. Meanwhile, however, certain actors in the stock market may have the power to manipulate stock prices, both to foment speculation that generates further price boosts on the upswing and to limit or offset the stock-price declines in the downturn. Alternatively, short-sellers who have sufficient financial power to manipulate the market may deliberately exacerbate stock-price declines. A major reason for the passage of the U.S. Securities Exchange Act of 1934, which established the Securities and Exchange Commission (SEC) as the federal government regulator of the stock market, was to prevent manipulation of stock prices. Senior corporate executives are often in a position to engage in stock-price manipulation by disseminating false or misleading financial information and by engaging in monopolistic product-pricing behavior. Since the early 1980s, however, the most ubiquitous, systemic, and direct way in which senior executives have been able, legally, to manipulate their companies' stock prices has been through stock repurchases, also known as stock buybacks. In the U.S. corporate economy over the decade 2006-2015, driven by massive stock buybacks, net equity issues were minus $\$ 4.1$ trillion. $^{5}$

Following our discussion of the drivers of the stock market, we then turn to an analysis of how, through their stock-based pay, corporate executives may be incentivized to make corporate resource-allocation decisions that can potentially result in product innovation but that can also influence stock-price speculation and implement stock-price manipulation, both of which inflate their stock-based pay. The "value-extracting CEO" hypothesis posits that, in the United States, a significant portion of senior executive compensation is rewarding them for making decisions that foment speculation and manipulate stock prices, thereby enabling them to extract value for their own personal gain. In support of this hypothesis, I present data on the total compensation of the 500 highest-paid corporate executives in the United States from 2006 through 2015 that show the magnitude of their total pay and the proportions of their average annual pay that have been in forms of realized gains from stock options and stock awards. In 2015, the average annual total compensation of the 500 highest-paid executives averaged $\$ 32.6$ million, with 46 percent from realized gains from the exercising of stock options and 36 percent from the vesting of stock awards

In section four of the paper, I invoke the theory of innovative enterprise (and a body of empirical research that underpins it) to support the hypothesis that the ways in which senior corporate executives are incentivized and rewarded undermines investment in productive capabilities. To drive home this argument, I debunk the dominant ideology that posits that, for the sake of superior economic performance, companies should be run to "maximize shareholder value" (MSV). My critique identifies two fundamental, but erroneous, assumptions of MSV ideology, as put forth by agency theory, ${ }^{6}$ that assert that a)

\footnotetext{
5 Board of Governors of the Federal Reserve System, Federal Reserve Statistical Release Z.1, "Financial Accounts of the United States: Flow of Funds, Balance Sheets, and Integrated Macroeconomic Accounts," Table F-223: Corporate Equities, September 16, 2016, at https://www.federalreserve.gov/releases/z1/current/.

6 For a prominent statement, see See Michael C. Jensen, "Agency Costs of Free Cash Flow, Corporate Finance, and Takeovers," American Economic Review, 76, 2, 1986: 323-329.
} 
of all participants in the corporate enterprise, only shareholders bear risk, thus giving them sole claim on corporate profits, if and when, they appear, and b) through the stock market, public shareholders are key parties who invest in the productive capabilities that the enterprise has available to it.

In place of agency theory, which is a theory of value extraction, I base my approach to analyzing the operation and performance of companies, and the economy in which corporations participate, on innovation theory, which is a theory of value creation. ${ }^{7}$ From the perspective of "the theory of innovative enterprise," we can address the question about how stock-based pay undermines investment in productive capabilities by focusing on its impact of three "social conditions of innovative enterprise" that are the essence of the firmlevel innovative process:

- Strategic control: For innovation to occur in the face of technological, market, and competitive uncertainties, executives who control corporate resource allocation must have the abilities and incentives to make strategic investments in innovation. Their abilities depend on their knowledge of how strategic investments in new capabilities can enhance the enterprise's existing productive capabilities. Their incentives depend on alignment of their personal interests with the company's purpose of generating innovative products. I argue that stock-based pay tends to undermine not only the incentives but also the abilities of those who exercise strategic control to allocate corporate resources to investments in productive capabilities.

- Organizational integration: The implementation of an innovative strategy requires the integration of people working in a complex division of labor into the collective and cumulative learning processes that are the essence of innovation. Work satisfaction, promotion, remuneration, and benefits are important instruments in a reward system that motivates and empowers employees to engage in collective learning over a sustained period of time. I argue that stock-based pay incentivizes corporate executives to underinvest in collective and cumulative learning processes and to dissipate the investments that the company has already made.

- Financial commitment: For collective learning to cumulate over time, the sustained commitment of "patient capital" must keep the learning organization intact. For a startup company, venture capital can provide financial commitment. For a going concern, retained earnings (leveraged if need be by debt issues) are the foundation of financial commitment. I argue that stock buybacks, incentivized by stock-based pay, deplete the corporation of internal financial resources that could otherwise form the foundation of financial commitment.

Finally, I elaborate the policy implications of the rise to economic power of the valueextracting CEO. These include a) banning stock buybacks, which in the United States will

\footnotetext{
7 William Lazonick, "The Chandlerian Corporation and the Theory of Innovative Enterprise," Industrial and Corporate Change, 19, 2, 2010: 317-349; William Lazonick, "Innovative Enterprise and Shareholder Value," Law and Financial Markets Review, 8, 1, 2014: 52-64; William Lazonick, "The Theory of Innovative Enterprise: Foundation of Economic Analysis," AIR Working Paper, August 2015, at www.theAIRnet.org; William Lazonick, "Innovative Enterprise or Sweatshop Economics? In Search of Foundations of Economic Analysis," Challenge, 59, 2, 2016: 65-114.
} 
entail a reversal of SEC Rule 10b-18, adopted in November 1982, that enables companies to do massive stock buybacks for the purpose of manipulating stock prices; b) requiring executive compensation that rewards innovation rather than speculation and manipulation, which as I explain in the concluding section, requires, as a start, a transformation of the measurement of executive pay from fictional "estimated fair value" numbers to factual "actual realized gains" numbers; 8 and c) placing stakeholders representing households as taxpayers, workers, and consumers on boards of directors of publicly listed companies, along with shareholders who represent households as savers. An intellectual precondition for these reforms is the rejection of the ideology that companies should be run to maximize shareholder value, which means replacing agency theory with innovation theory as a mode of analyzing how the operation of an economy, supported by the strategies and structures of the business enterprises within it, can attain the objectives of stable and equitable economic growth.

\section{Drivers of the Stock Market}

There are three possible drivers of stock prices: innovation, speculation, and manipulation. ${ }^{9}$

Take the case of Cisco Systems, which did its initial public offering (IPO) on the NASDAQ stock exchange on February 16, 1990. Cisco shares that cost $\$ 1,000$ at the IPO had a market value of $\$ 389,000$ at the end of 2015. Meanwhile, however, as can be seen in Figure 1, during that quarter century, Cisco's stock price underwent dramatic fluctuations, driven in different periods primarily (although obviously not wholly) by innovation, speculation, or manipulation.

One can posit that during the first seven to eight years of its existence as a public company, innovation was the primary driver of the increase in Cisco's stock price as stock-market traders observed, after the fact, that the company was generating high levels of profit by becoming the dominant competitor in the new and booming Internet equipment market. In October 1998, at the end of this innovation phase, Charles O'Reilly, a professor at Stanford Business School, published a case that began with the statement, "Cisco is a $\$ 6$ billion high technology stealth company, largely unknown to the general public."10 Yet at that point Cisco was already the fastest growing company in history, with shares bought for $\$ 1,000$ at the company's IPO worth $\$ 185,000$ at the beginning of October 1998.

From November 1998 to March 2000, however, this "largely unknown" company was the focus of intense stock-market speculation, with its stock price rising by almost seven times, giving Cisco the highest market capitalization in the world in March 2000. At its all-time stock-price peak on March 21, 2000, those $\$ 1,000$ in shares bought at the IPO were worth over \$1 million. In May 2000, Thomas Donlan, a Barron's editor, calculated that to justify

8 Hopkins and Lazonick, "The Mismeasure of Mammon"; Matt Hopkins and William Lazonick, "Corporate executives are making way more money than anyone reports," The Atlantic, September 15, 2016, at

http://www.theatlantic.com/business/archive/2016/09/executives-making-way-more-than-reported/499850/

9 William Lazonick, "The New Economy Business Model and the Crisis of U.S. Capitalism," Capitalism and Society, 4, 2 , 2009: Article 4.

10 Charles A. O'Reilly, “Cisco Systems: The Acquisition of Technology is the Acquisition of People," Stanford Business School Case HR10, Graduate School of Business, Stanford University, October 1998. 
its stock price, which stood at 190 times earnings, Cisco would have to increase its 1999 profits of $\$ 2.5$ billion to $\$ 2.5$ trillion by $2010 ! 11$

This speculation had a profound impact on stock-based pay. Cisco CEO John Chambers received total compensation of $\$ 121.7$ million in 1999 and $\$ 156.3$ million in 2000, with over 99 percent in each year coming from realized gains from exercising stock options. Cisco's other four highest-paid executives averaged \$25.9 million in 1999 (96 percent from options) and \$38.0 million in 2000 (97 percent from options). Indeed, with its broad-based stock-option plan, the average realized gains from exercising stock options at Cisco was (not including the five highest-paid executives, whose incomes we know) an estimated $\$ 193,500$ across an average of 18,000 employees in 1999 and $\$ 290,900$ across an average of 27,500 employees in $2000 .{ }^{12}$

Figure 1. Stock-price movements, Intel (INTC), Microsoft (MSFT), and Cisco (CSCO), and the NASDAQ Composite Index, and prime drivers of stock prices, March 26, 1990-June 30, 2016 (March 26, 1990=100)

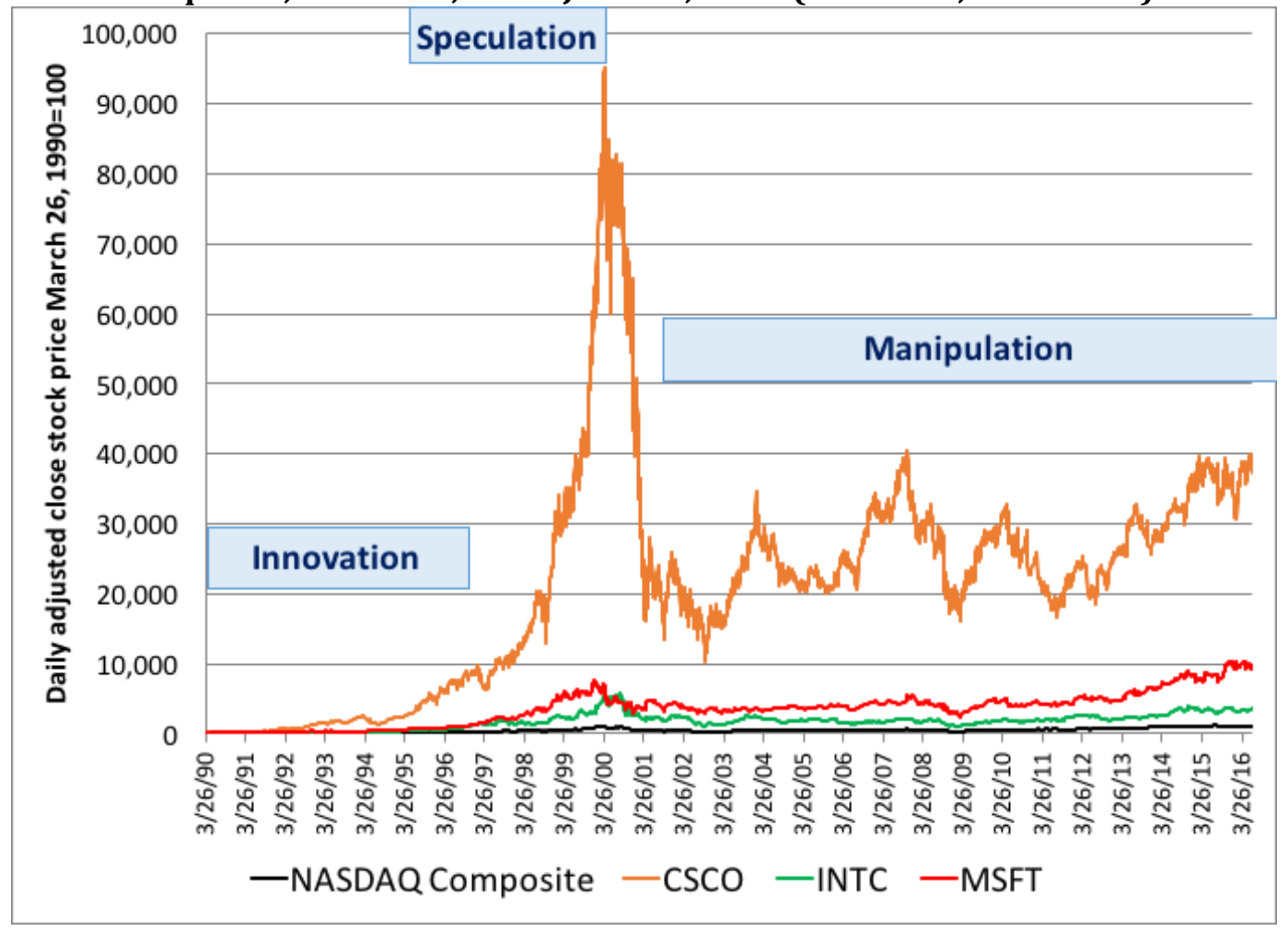

Source: Yahoo! Finance, daily data, adjusted close.

Then, with the bursting of the Internet bubble, between March 2000 and September 2001, Cisco's stock price plunged by 85 percent, at which point the company entered into the manipulation phase of its stock-price determination as it began doing stock buybacks. Cisco repurchased $\$ 1.9$ billion in fiscal 2002 (year ending July 27, 2002), $\$ 6.0$ billion in 2003, $\$ 9.1$ billion in 2004, and $\$ 10.2$ billion in 2005. Since then through 2016, Cisco's buybacks ranged from a high of $\$ 10.4$ billion in 2008 to a low of $\$ 3.1$ billion in 2013. From 2002

11 Thomas G. Donlan, “Cisco’s bids: Its growth by acquisition will cause problems.” Barron's, May 8. 2000: 31-34.

12 See William Lazonick, Sustainable Prosperity in the New Economy? Business Organization and High-Tech Employment in the United States, W. E. Upjohn Institute for Employment Research, 2009, pp. 48-66. 
through 2016, Cisco expended $\$ 97.5$ billion on repurchases, equal to 95 percent of its net income, while since 2011 the company also paid shareholders $\$ 18.1$ billion in dividends. With neither innovation nor speculation driving Cisco's stock price, the purpose of these massive buybacks has been to manipulate it. Those executives who have been able to take advantage of the price boosts through the timing of their option exercises and stock sales and by hitting stock-related performance targets that trigger vesting of stock awards have enhanced their realized gains from stock options and stock awards.

The dramatic rise and fall of Cisco's stock price in the Internet boom and bust make the stock-price movements of Intel, Microsoft, and the NASDAQ Composite Index, as shown in Figure 1, appear as mere blips. Figure 2, with a more limited stock-price scale, shows similar price movements for Intel, Microsoft, and the NASDAQ Index (in which Intel, Microsoft, and Cisco are included). I posit that over the past quarter century the stock prices of Intel and Microsoft followed a similar sequence to Cisco's innovation, speculation, and manipulation phases. One difference is that, with speculation in its stock rampant, Cisco did no buybacks in 1998-2000, whereas Intel did $\$ 15.4$ billion and Microsoft $\$ 10.3$ billion in these years, both companies trying to maintain pace with Cisco's exploding stock price as well as offset the dilution of the companies' shareholdings as employees exercised their options. Like Cisco, both Intel and Microsoft have done massive buybacks to manipulate their stock prices since the Internet boom turned to bust: $\$ 85.7$ billion by Intel from 2001 through the third quarter of 2016 (ending October 1, 2016) and $\$ 163.0$ billion by Microsoft from 2001 through the first quarter of 2016 (ending September 30, 2016).

Figure 2. Stock-price movements, Intel (INTC), Microsoft (MSFT) and the NASDAQ Composite Index, and prime drivers of stock prices, March 26, 1990-June 30, 2016 (March 26, 1990=100)

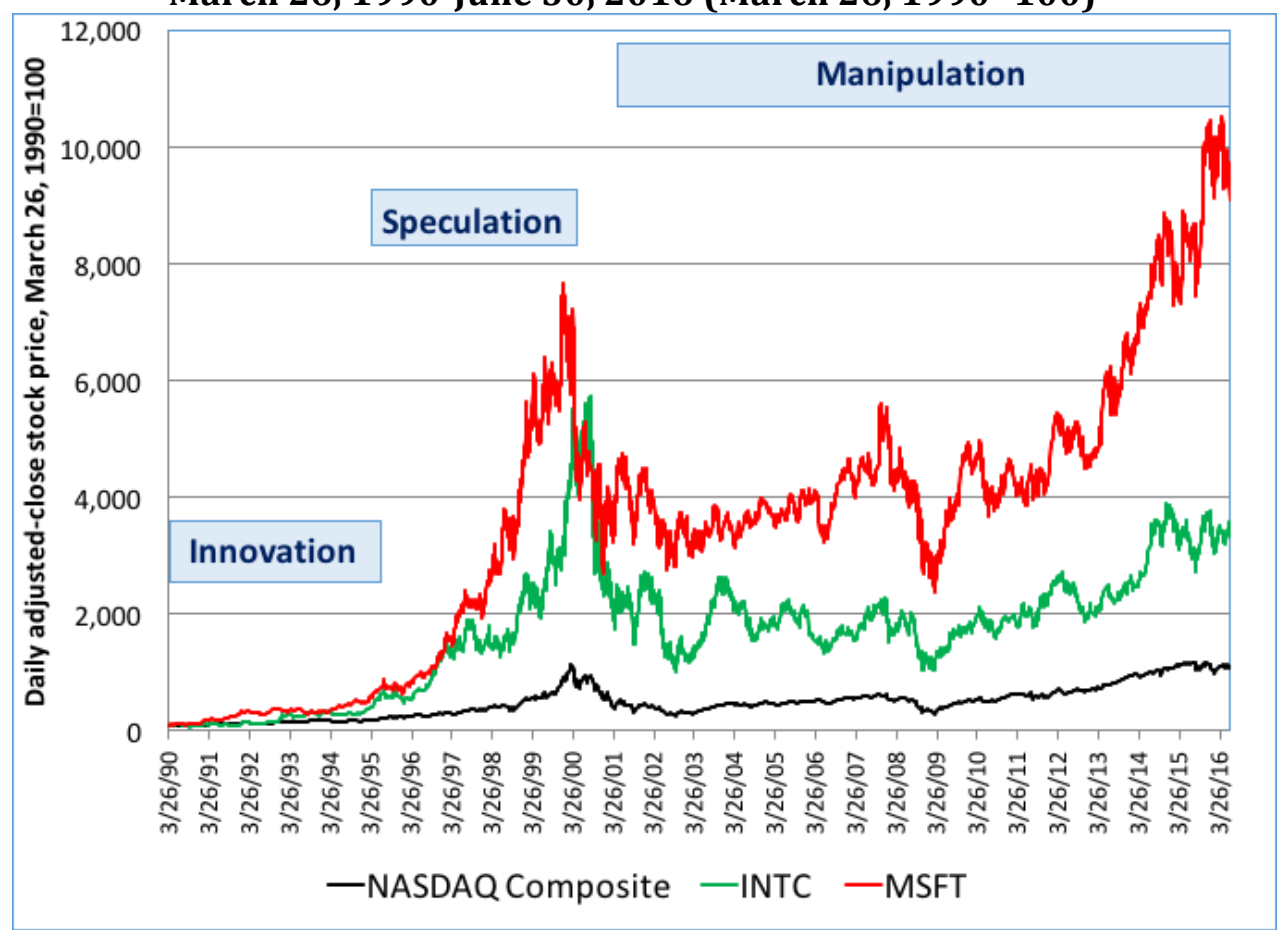

Source: Yahoo! Finance, daily data, adjusted close. 
More generally, the stock market rewards innovative enterprise after the fact, once the innovations have been successful. In the case of startups, venture capitalists can use the stock market to do an IPO and thereby, with the company listed on the stock market, "exit" their investments by selling on the market part or all of their shareholdings. The rapidity of the time period from the founding of a company to an IPO is of prime importance to venture capitalists. Prior to the 1970s the dominant New York Stock Exchange had stringent listing requirements in terms of profitability record and capitalization level that generally precluded an IPO just a few years after the founding of a company. The 1971 launching of NASDAQ - the National Association of Security Dealers Automated Quotation system-dramatically truncated the lag from startup to IPO by dramatically lowering the listing requirements. Intel, founded in 1968, went public on NASDAQ as soon as the new electronic exchange opened in 1971. As a pioneering application of computer networking, the emergence of NASDAQ as a highly liquid national stock exchange on which new ventures could do IPOs just a few years after startup was critical to the emergence from 1972 of the organized venture-capital industry that has become integral to high-tech industry in the U.S. economy. ${ }^{13}$

As occurred on NASDAQ in the last half of the 1990s-and as we have seen for the cases of Intel, Microsoft, and Cisco-stock-price increases driven by innovation can transform into bubbles driven by speculation. In such an environment, profitless and even productless companies may be able to use speculation to raise substantial amounts of cash on the stock market, making their shareholders super-rich. In some cases, such as Amazon with its 1997 IPO when it was unprofitable, successful companies may eventually emerge from these speculative IPOs. But given widespread, and in some cases spectacular, failures, this speculative funding of young companies that a listing on NASDAQ permits may represent a major misallocation of resources. ${ }^{14}$

A case in point was Sycamore Networks, an optical networking company founded in February 1998 and located in Boston's Route 128 high-tech district. ${ }^{15}$ With one customer (whose executives were given Sycamore shares), previous year revenues of $\$ 11$ million, losses of \$19 million, and 155 employees, Sycamore did its IPO in October 1999, and was able to translate the "New Economy" hype into a \$284-million infusion of cash for less than 10 percent of its outstanding shares. In December 1999 Sycamore ranked 117th in market capitalization in the United States, just behind Emerson Electric, a company founded in 1890 that had revenues of $\$ 14.3$ billion and 117,000 employees! ${ }^{16}$ Sycamore then did a secondary offering in March 2000, at the very apex of the boom, with its stock price at $\$ 150$, and netted another $\$ 1.2$ billion for the corporate treasury.

13 Lazonick, Sustainable Prosperity in the New Economy?, ch. 2

14 John Cassidy, Dot.Con: The Greatest Story Ever Sold, Harper, 2002; Mark Gimein, "You bought. They sold." Fortune, September 2, 2002, at http://www.markgimein.com/pages/greed.pdf.

15 See William Lazonick, "The US Stock Market and the Governance of Innovative Enterprise," Industrial and Corporate Change, 16, 6, 2007, pp 1021-1022.

16 In 2015, with 110,800 employees, Emerson was in the identical $118^{\text {th }}$ place in market capitalization, while Sycamore has been liquidated three years earlier. "Emerson Electric now 118th largest company, surpassing Reynolds American," The Online Investor, April 13, 2015, at https://www.theonlineinvestor.com/article/201504/emerson-electric-now118-largest-company-surpassing-reynolds-american-EMR04132015mbumped.htm/. See also Emerson on the Fortune 500 list, published in 2016, for ranking by revenue in 2015, at http://beta.fortune.com/fortune500/emerson-electric128. 
At the same time, top executives and board members of Sycamore sold a portion of their own stockholdings for $\$ 726$ million. ${ }^{17}$ By September 2001, its stock price had plunged to as low as $\$ 3.80$, and it never recovered to a significant extent. In 2001 Sycamore had what turned out to be peaks of $\$ 375$ million in revenues and 944 employees, but the company never became profitable. After distributing $\$ 470$ million in dividends in 2010 and 2011money still remaining as the result of its secondary issue in March 2000-Sycamore went out of business in 2012, having racked up losses of $\$ 875$ million over its 14-year history as a public company. ${ }^{18}$ Taken in by the hype of the Internet boom, the stock-market speculators who endowed the company with $\$ 1.5$ billion in 1999 and 2000 were in effect "accidental" venture capitalists who lost their money betting on a company that proclaimed its innovative future but never generated the innovative products to deliver on it.

Besides the allocation of inordinate amounts of resources to unproductive New Economy startups, the speculative boom of the late 1990s helped inflict even greater damage to the innovative capabilities of some established Old Economy companies whose top executives also got caught up in the New Economy hype. ${ }^{19}$ In 2000 Lucent Technologies-formerly Western Electric and then AT\&T Technologies, with a history dating back to 1869-was the largest communication technology company in the world. Yet in 1998 through 2000, its top executives made resource-allocation decisions that contributed to the dramatic post-2000 decline of the company. In particular, they lavished massive amounts of the company's stock on "New Economy" acquisitions that it then failed to integrate into the organization. The most expensive acquisitions were done to convince the stock market that Lucent was an agile New Economy company. Yet, enriched by their equity stakes in the acquired company, key personnel of the acquisitions exhibited their individual agility by leaving Lucent to launch new companies, become angel investors, take jobs at other hyped startups, or just retire. In the Internet crash of 2001-2002, to stave off bankruptcy, Lucent had to sell stock at one or two percent of its price in the boom, and by 2006 , the vastly weakened company was taken over by its French rival Alcatel. ${ }^{20}$

While an Old Economy company such as Lucent was destroying itself by using its stock to pay highly speculative prices to acquire New Economy startups that lacked proven products, other Old Economy companies were making a transition to the "New Economy business model" by doing large-scale stock buybacks to give manipulative boosts to their stock prices. In the information-technology industry, the leading Old Economy companies were International Business Machines (IBM) and Hewlett-Packard (HP). In pharmaceuticals, the leading companies were Pfizer and Merck. Table 1 shows the distributions to shareholders-dividends and buybacks-by these four companies by

\footnotetext{
17 Gimein, "You bought. They sold."

18 Steven Syre, "Internet-era boom icon's quiet bust," Boston Globe, October 26, 2012, at

https://www.bostonglobe.com/business/2012/10/25/quiet-end-for-sycamore-networks-brief-star-internetera/7GA6J0LQ1bz6NMrms4osoN/story.html

19 Marie Carpenter, William Lazonick, and Mary O'Sullivan "The Stock Market and Innovative Capability in the New Economy: The Optical Networking Industry," Industrial and Corporate Change, 12, 5, 2003: 963-1034; William Lazonick and Edward March, "The Rise and Demise of Lucent Technologies," Journal of Strategic Management Education, 7, 4, 2011. For the distinction between Old Economy and New Economy companies, see Lazonick, Sustainable Prosperity in the New Economy?, chs. 2 and 3. This book focuses on the information-and-communication-technology industries. For the problem of product-less IPOs in biotechnology, see William Lazonick and Öner Tulum, "US Biopharmaceutical Finance and the Sustainability of the Biotech Business Model," Research Policy, 40, 9, 2011: 1170-1187

${ }^{20}$ Lazonick and March, "The Rise and Demise of Lucent Technologies."
} 
decade from 1976-2015, in absolute terms and as percentages of net income. Buybacks are by no means new at these companies, but they have become massive over the decades, even as dividends have increased. All four of these companies have made a transition from innovation to financialization-that is, from an orientation to value creation to an orientation to value extraction. ${ }^{21}$

Table 1. Net income (NI), cash dividends (DV), and stock buybacks (BB) at HP, IBM, Merck, and Pfizer, 1976-2015

\begin{tabular}{|c|c|c|c|c|c|c|}
\hline & NI, \$m & $\mathrm{DV}, \$ \mathrm{~m}$ & BB, \$m & DV/NI\% & BB/NI\% & $\begin{array}{c}(\mathrm{DV}+\mathrm{BB}) / \\
\mathrm{NI} \%\end{array}$ \\
\hline \multicolumn{7}{|l|}{ HP } \\
\hline 1976-1985 & 3,118 & 281 & 382 & 9.0 & 12.3 & 21.3 \\
\hline 1986-1995 & 10,057 & 1,541 & 4,150 & 15.3 & 41.3 & 56.6 \\
\hline 1996-2005 & 23,777 & 7,192 & 21,935 & 30.2 & 92.3 & 122.5 \\
\hline $2006-2015$ & 47,316 & 9,471 & 63,347 & 20.0 & 133.9 & 153.9 \\
\hline \multicolumn{7}{|l|}{ IBM } \\
\hline 1976-1985 & 41,140 & 19,929 & 3,151 & 48.4 & 7.7 & 56.1 \\
\hline 1986-1995 & 16,937 & 21,209 & 12,017 & 125.2 & 71.0 & 196.2 \\
\hline 1996-2005 & 68,904 & 9,611 & 52,406 & 13.9 & 76.1 & 90.0 \\
\hline $2006-2015$ & 134,656 & 32,918 & 117,799 & 24.4 & 87.5 & 111.9 \\
\hline \multicolumn{7}{|l|}{ Merck } \\
\hline 1976-1985 & 3,948 & 1,760 & 595 & 44.6 & 15.1 & 59.7 \\
\hline 1986-1995 & 18,670 & 8,624 & 6,146 & 46.2 & 32.9 & 79.1 \\
\hline 1996-2005 & 58,163 & 27,657 & 25,825 & 47.6 & 44.4 & 92.0 \\
\hline $2006-2015$ & 51,147 & 43,929 & 29,667 & 85.9 & 58.0 & 143.9 \\
\hline \multicolumn{7}{|l|}{ Pfizer } \\
\hline 1976-1985 & 3,123 & 1,343 & 66 & 43.0 & 2.1 & 45.1 \\
\hline 1986-1995 & 8,686 & 4,370 & 3,249 & 50.3 & 37.4 & 87.7 \\
\hline 1996-2005 & 54,668 & 26,846 & 38,184 & 49.1 & 69.8 & 119.0 \\
\hline 2006-2015 & 115,170 & 67,968 & 63,151 & 59.0 & 54.8 & 113.8 \\
\hline
\end{tabular}

Source: Standard and Poor's Compustat database

Large-scale buybacks on a persistent basis began in the mid-1980s, after the SEC adopted Rule 10b-18 in November 1982.22 Rule 10b-18 gives a company a "safe harbor" against manipulation charges in doing open-market repurchases. The safe harbor states that a company will not be charged with manipulation if, among other things, its buybacks on any single day are no more than 25 percent of the previous four weeks' average daily trading volume (ADTV). While remaining within the safe harbor, a large company can often do hundreds of millions of dollars in buybacks per day, and, if its top executives so choose, it can do so repeatedly, trading day after trading day. On December 2, 2016, the safe-harbor daily limits were $\$ 142$ million for IBM, \$54 million for HP, \$171 million for Merck, and

\footnotetext{
${ }^{21}$ Lazonick, Sustainable Prosperity in the New Economy?, chs. 2 and 3; William Lazonick, Matt Hopkins, Ken Jacobson, Mustafa Erdem Sakinç, and Öner Tulum, “U.S. Pharma's Business Model: Why It Is Broken, and How It Can Be Fixed," in David Tyfield, Rebecca Lave, Samuel Randalls, and Charles Thorpe, eds., The Routledge Handbook of the Political Economy of Science, Routledge, forthcoming.

22 William Lazonick, "Stock Buybacks: From Retain-and-Reinvest to Downsize-and-Distribute," Center for Effective Public Management, Brookings Institution, April 2015, pp. 10-11, at http://www.brookings.edu/research/papers/2015/04/17-stock-buybacks-lazonick; Ken Jacobson and William Lazonick, "SEC Rule 10b-18: A License to Loot," presentation to the annual conference of the Society for the Advancement of Socio-Economics, London School of Economics, July 3, 2015.
} 
$\$ 290$ million for Pfizer. For Cisco, Intel, and Microsoft, discussed previously, these ADTV numbers were $\$ 200$ million, $\$ 167$ million, and $\$ 435$ million, respectively. Under Rule 10b18 , moreover, there is no presumption of manipulation should the corporation's repurchases exceed the 25 percent ADTV limit.

Buybacks have come to define the "investment" strategies of many of America's biggest businesses. Figure 3 shows net equity issues of U.S. corporations from 1946 to 2015. Net equity issues are new corporate stock issues minus outstanding stock retired through stock repurchases and M\&A activity. Since the mid-1980s, in aggregate, corporations have funded the stock market rather than vice versa (as is conventionally assumed). Over the decade 2006-2015 net equity issues of nonfinancial corporations averaged minus $\$ 416$ billion per year. ${ }^{23}$ For 2016, at the time of writing, net equity issues are at an annual rate of $\$ 540$ billion. Over the past three decades, in aggregate, dividends have tended to increase as a proportion of corporate profits. Yet in 1997, for the first time, buybacks surpassed dividends in the U.S. corporate economy and, even with dividends increasing, have far exceeded them in recent stock-market booms.

Figure 3: Net equity issues, U.S. nonfinancial and financial companies, 1946-2015

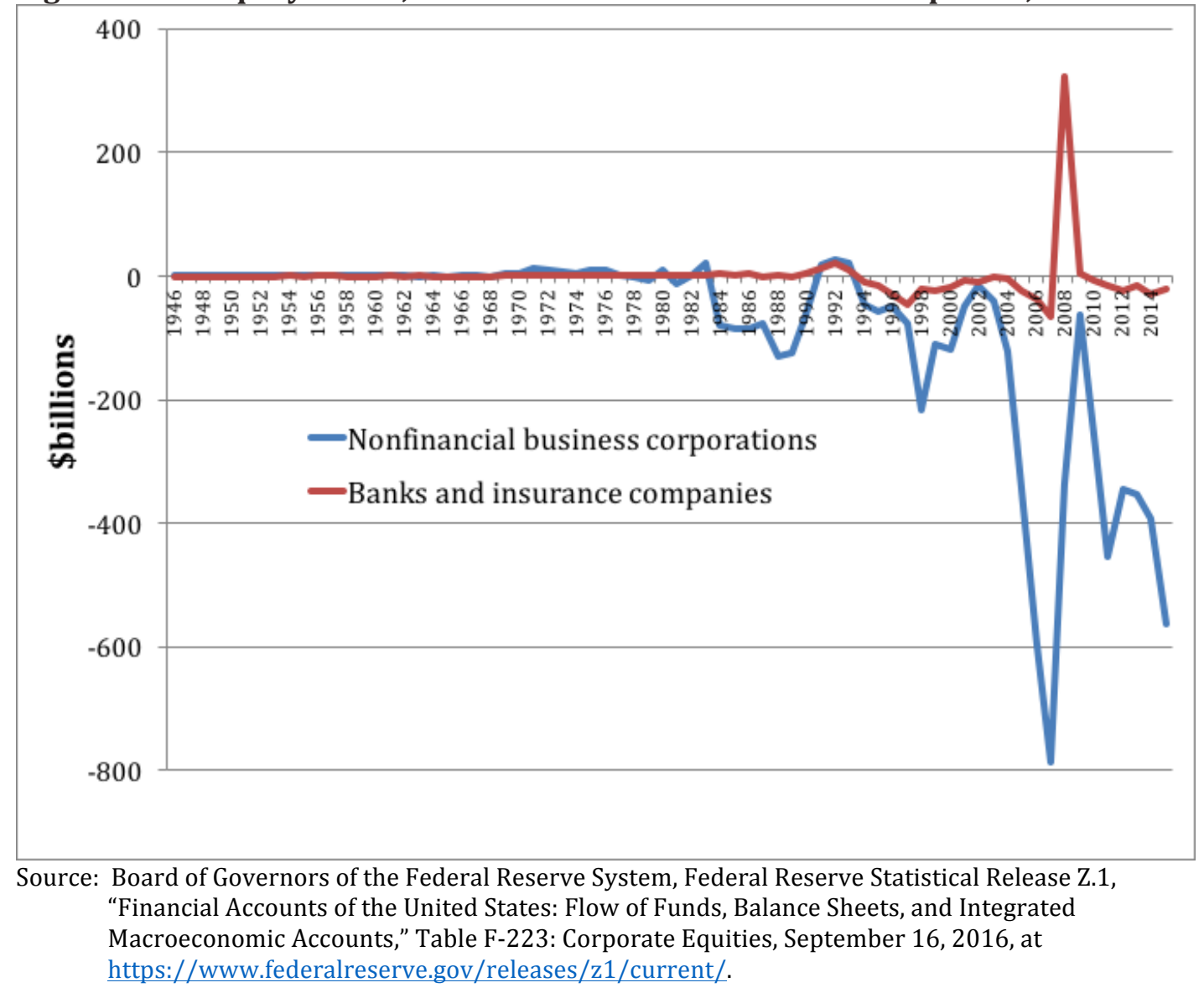

23 The spike in equity issues for financial corporations in 2009 occurred when some of the largest among them sold stock to the U.S. government in the financial-crisis bailout. The banks that were bailed out had been major repurchasers of their own stock in the years before the financial meltdown. See William Lazonick, "Everyone is paying the price for share buy-backs," Financial Times, September 26, 3008, p. 25; William Lazonick, "The buyback boondoggle,"

BusinessWeek, August 24 \& 31, 2009, p. 96. 
Using the data in Figure 3, Table 2 shows the amounts of net equity issues, decade by decade, from 1946 to 2015, in 2015 dollars. For the first three decades after World War II, net equity issues were moderately positive in the corporate economy as a whole. In the following decades, however, net equity issues became increasingly negative (even after adjusting for inflation) and, as a gauge of their growing importance in the economy, represented a rising proportion of GDP.

Table 2. Net equity issues in the U.S. economy, by decade in 2015 dollars, and as a percent of GDP

\begin{tabular}{|c|c|c|}
\hline & $\begin{array}{c}\text { NET EQUITY } \\
\text { ISSUES, } \\
2015 \text { \$ BILLIONS }\end{array}$ & $\begin{array}{c}\text { NET EQUITY } \\
\text { ISSUES AS } \\
\% \text { OF GDP }\end{array}$ \\
\hline $1946-1955$ & $\mathbf{1 4 3 . 2}$ & $\mathbf{0 . 5 6}$ \\
\hline $1956-1965$ & $\mathbf{1 1 0 . 9}$ & $\mathbf{0 . 3 0}$ \\
\hline $1966-1975$ & $\mathbf{3 1 6 . 0}$ & $\mathbf{0 . 5 8}$ \\
\hline $1976-1985$ & $\mathbf{- 2 9 0 . 9}$ & $\mathbf{- 0 . 4 0}$ \\
\hline $1986-1995$ & $\mathbf{- 1 , 0 0 2 . 5}$ & $\mathbf{- 1 . 0 0}$ \\
\hline $1996-2005$ & $\mathbf{- 1 , 5 2 4 . 4}$ & $\mathbf{- 1 . 0 9}$ \\
\hline $2006-2015$ & $\mathbf{- 4 , 4 6 6 . 6}$ & $\mathbf{- 2 . 6 5}$ \\
\hline
\end{tabular}

Retained earnings have always been the financial foundation for business investment in innovation and sustained employment. These retentions can fund investment in plant and equipment, research and development, and, of critical importance, training and retaining employees. If dividends alone are too high, investments in the company's productive capabilities will suffer. The addition of buybacks to dividends over the past three decades reflects a failure of corporate executives to develop strategies for investing in the productive capabilities of the companies over which they exercise strategic control.

Dividends are the traditional and legitimate way for a publicly listed corporation to provide income to shareholders. Dividends provide shareholders with an income for (as the name says) holding shares. Moreover, if the firm retains enough of its profits to finance further investment in the company's productive capabilities, there is the possibility (although by no means the certainty) that it will generate competitive products that, through innovation, will help lift its future stock price and the value of the shares held. When, for whatever reason, shareholders who have benefited from a stream of income on their holdings decide to sell some or all of their shares, they stand to make a capital gain.

In contrast, by creating demand for the company's stock that provides an immediate manipulative boost to its stock price, buybacks reward those shareholders who sell their shares. The most prominent sharesellers are those stock-market traders, including corporate executives, investment bankers, and hedge-fund managers, who are able to time their stock sales to take advantage of buyback activity done as open-market repurchases. Buybacks also automatically increase earnings per share (EPS) by decreasing the number of shares outstanding. Since EPS has become a major metric by which financial interests evaluate the performance of a company, buybacks tend to increase demand for a 
company's stock, thus creating opportunities for stock-market traders to sell their shares at a gain even in the absence of increased corporate revenues or profits.

As shown in Figure 4, since the early 1980s, major U.S. business corporations have been doing stock buybacks on top of (not instead of) making dividend payments to shareholders. Figure 4 shows dividends and buybacks for 236 companies that were in the S\&P 500 Index in January 2016 that were publicly listed from 1981 through 2015. At the beginning of the 1980s, buybacks were minimal, and from 1981 through 1983 buybacks for these 236 companies absorbed only 4.3 percent of net income, with dividends representing 49.5 percent. The buyback proportion of net income increased to 18.8 percent in 1984 and 30.8 percent in 1985, while the dividend proportions were 42.5 percent and 52.4 percent. Thereafter, by ten-year periods, the buyback proportions of net income increased from 25.8 percent in 1986-1995 to 42.9 percent in 1996-2005 and 49.5 percent in 2006-2015, while dividend payouts over these decadal periods were 50.7 percent, 39.0 percent, and 39.1 percent, respectively. Even though dividend payout ratios were lower in 1996-2005 and 2006-2015 than in 1986-1995, total payout ratios to shareholders rose from 76.5 percent to 81.9 percent to 88.6 percent over these three periods. Most recently, the total payout ratios for these 236 companies were 97.0 percent in 2014 and 106.2 percent in 2015.

Figure 4. Mean cash-dividend and stock-buyback distributions in 2015 dollars for 236 companies in the S\&P 500 Index in January 2016 that were publicly listed from 1981 through 2015

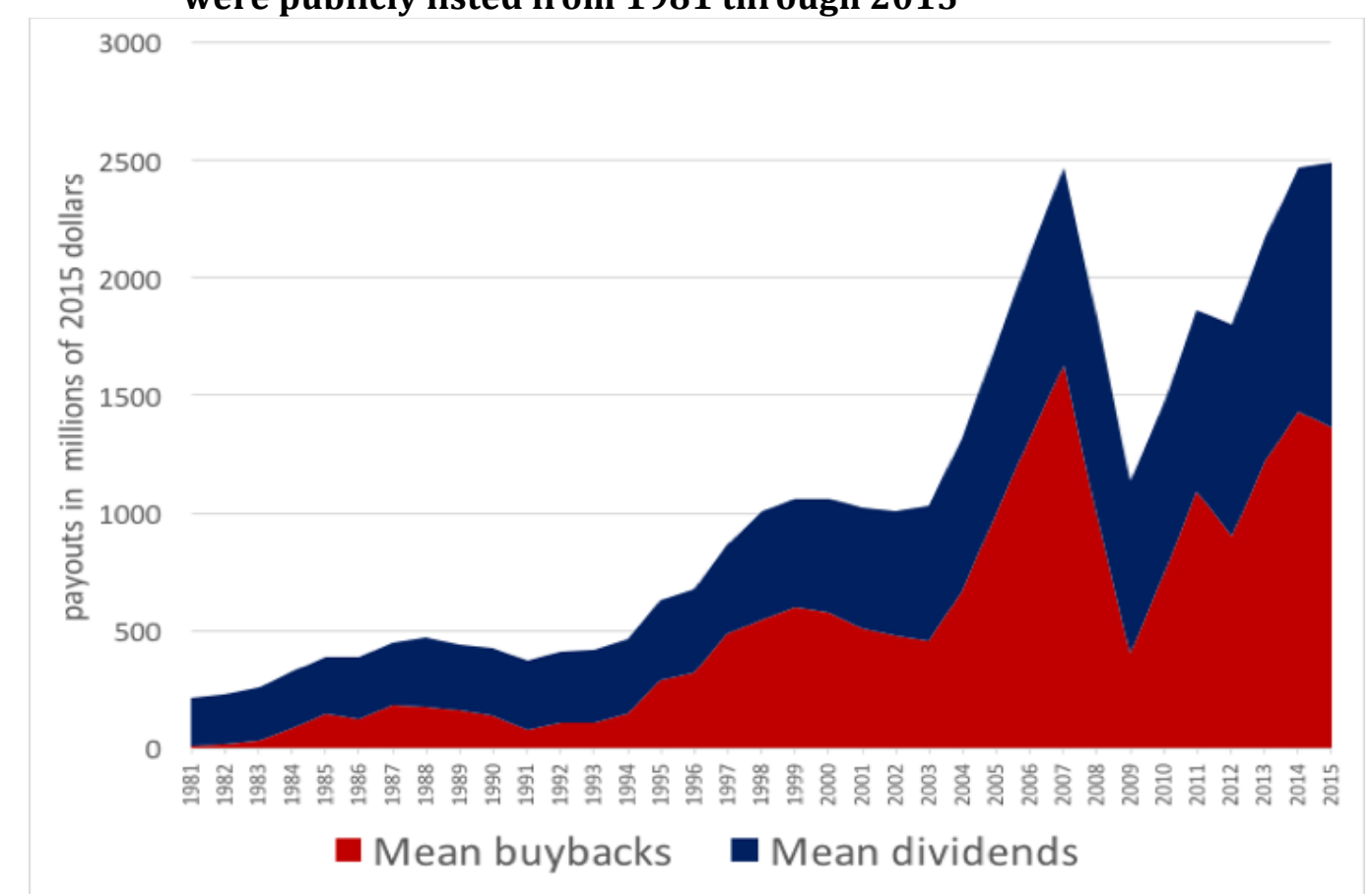

Source: Standard and Poor's Compustat database; calculations by Mustafa Erdem Sakinç and Emre Gomeç of the Academic-Industry Research Network.

Over the years 2006-2015, the 459 companies in the S\&P 500 Index in January 2016 that were publicly listed over the ten-year period expended $\$ 3.9$ trillion on stock buybacks, representing 53.6 percent of net income, plus another 36.7 percent of net income on 
dividends. Much of the remaining 9.7 percent of profits was held abroad, sheltered from U.S. taxes. As shown in Figure 5, mean buybacks for these 459 companies ranged from $\$ 291$ million in 2009, when the stock markets had collapsed, to $\$ 1,205$ million in 2007 , when the stock market peaked before the Great Financial Crisis. In 2015, with the stock market booming, mean buybacks for these companies were $\$ 1,173$ million. Meanwhile, dividends declined moderately in 2009, but over the period 2006-2015 they trended up in real terms (the data in Figure 5 have not been adjusted for inflation). Many of America's largest corporations routinely distribute more than 100 percent of net income to shareholders, generating the extra cash by reducing cash reserves, selling off assets, taking on debt, or laying off employees. ${ }^{24}$

Figure 5. Mean stock buybacks (BB) and cash dividends (DV), and ratios to net income (NI) for 459 companies in in the S\&P 500 Index in January 2016 that were publicly listed from 2006 through 2015

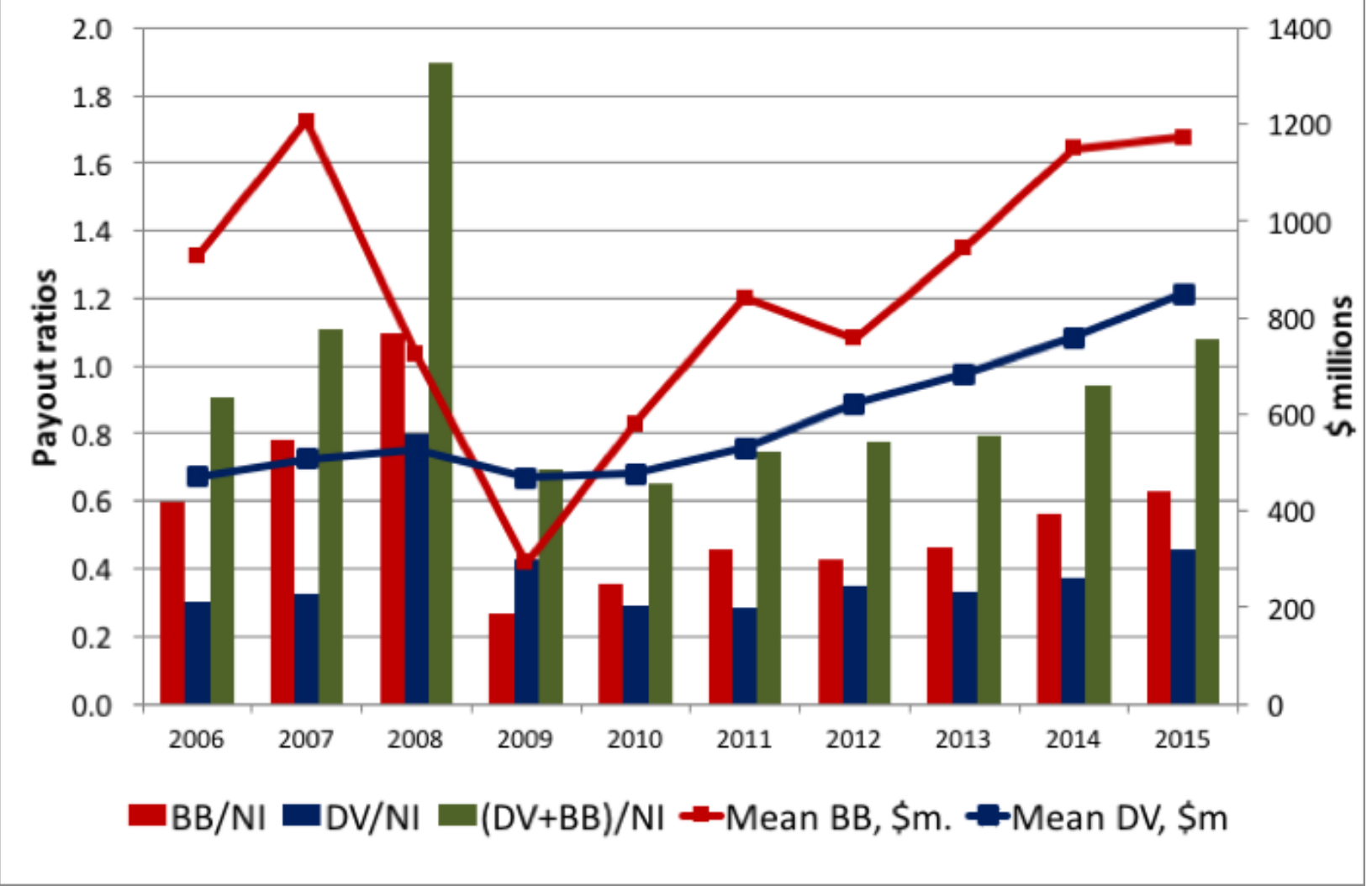

Source: Standard and Poor's Compustat database; calculations by Mustafa Erdem Sakinç and Emre Gomeç of the Academic-Industry Research Network.

\section{Stock-Based Compensation}

In the United States, a company's board of directors can authorize a stock buyback program

${ }^{24}$ Lazonick, "Labor in the Twenty-First Century": William Lazonick, "How Stock Buybacks Make Americans Vulnerable to Globalization," Paper presented at the Workshop on Mega-Regionalism: New Challenges for Trade and Innovation, East-West Center, University of Hawaii, Honolulu, January 20-21, 2016, at

http://papers.ssrn.com/sol3/papers.cfm?abstract_id=2745387; 
of a certain amount (say $\$ 10$ billion) over a certain period of time (say three years). It is then at the discretion of the CEO, presumably in agreement with the company's chief financial officer (CFO), to do a chosen amount of buybacks as open-market repurchases on any given day. Within the scope of the buyback program and subject to the restrictions contained in Rule 10b-18, the CEO and CFO can then implement buybacks sporadically or for a series of days, as they see fit. Little is known about this decision-making process. Indeed, under Rule 10b-18, a company does not need to disclose, even after the fact, the particularly days on which it does stock buybacks.

Since 2004, the SEC has required quarterly reports on buyback activity in a company's 10Q filing, with the monthly volume and value of buybacks and the weighted average repurchase price. But, even with SEC Rule 10b5-1,25 adopted in 2000 to increase disclosure of material information that could be used for insider trading, the failure of the SEC to require reporting of the precise days on which buybacks are done creates opportunities for senior executives who are in the know to trade on this insider information without being detected, except possibly by the SEC launching a special investigation. ${ }^{26}$ And in the more than three decades that Rule $10 \mathrm{~b}-18$ has been in force, the SEC has never investigated the use of insider information on the timing of open-market repurchases for personal gain. ${ }^{27}$

Corporate executives, or the academics who provide apologetics for them, give three reasons for doing buybacks that portray this mode of resource allocation as being in the best interest of the company. All these reasons are, however, deeply flawed:28

- Executives may claim that buybacks are done when the company is mature and new investment opportunities have vanished. But any CEO who makes this argument is not doing his or her job of devising a strategy to invest in the company's future. In fact, it is generally financial economists, seeking to rationalize buybacks, who make this claim. ${ }^{29}$ CEOs are generally smart enough to recognize how such a justification for buybacks would call their leadership capabilities into question.

- Executives often claim that, in repurchasing stock, they are making an investment in the company because the market undervalues its shares. But the evidence is overwhelming

\footnotetext{
25 Securities and Exchange Commission, "Final Rule: Selective Disclosure and Insider Trading," August 15, 2000, at https://www.sec.gov/rules/final/33-7881.htm

${ }^{26}$ See, for example, Jesse Eisinger, "Repeated good fortune in timing of CEO's stock sale," New York Times Dealbook, February 19, 2014, at http://dealbook.nytimes.com/2014/02/19/repeated-good-fortune-in-timing-of-c-e-o-s-stocksale/

27 See the letters by U.S. Sen. Tammy Baldwin to SEC Chair Mary Jo White of April 23, 2015, at (www.baldwin.senate.gov/imo/media/doc/Baldwin\%20Letter\%20to\%20SEC\%204\%2023\%2015.pdf) and November 16, 2015 (www.baldwin.senate.gov/imo/media/doc/111615\%20Letter\%20to\%20SEC.pdf) and Chair White's responses of July 13, 2015 (www.documentcloud.org/documents/2272283-sec-response-to-baldwin07132015.html\#document/p1) and January 29, 2016 (copy in the possession of the authors). See also David Dayen, "SEC admits it's not monitoring stock buybacks to prevent market manipulation," The Intercept, August 12, 2015, at https://theintercept.com/2015/08/13/sec-admits-monitoring-stock-buybacks-prevent-market-manipulation/.

28 William Lazonick, "Profits Without Prosperity: Stock Buybacks Manipulate the Market and Leave Most Americans Worse Off," Harvard Business Review, September 2014, 46-55

${ }^{29}$ See, for example, Theodoros Evgeniou and Theo Vermaelen, "Is Hillary Clinton right about share buybacks?" INSEAD Knowledge, September 23, 2016, at http://knowledge.insead.edu/economics-finance/is-hillary-clinton-right-aboutshare-buybacks-4941.
} 
that most buybacks are carried out when stock prices are high, not when they are low. Moreover, by this explanation, we would expect a company to bolster the corporate treasury by selling its shares on the market when they are overvalued in a speculative boom - as indeed U.S. corporations did in the boom of the late 1920s. ${ }^{30}$ But in the era of "maximizing shareholder value," a stock issue in a boom would send a signal to the market that would depress the company's stock price. It does sometimes happen, as was the case with General Electric in 2008, that a company that has recently done buybacks at a high price is then compelled to sell its stock at a low price when an unexpected downturn puts it in financial difficulty. ${ }^{31}$

- Executives sometimes claim that their companies do buybacks to offset dilution of EPS that results when employees exercise stock options that they have received as part of their compensation. But if stock-based pay is supposed to induce employees to work harder and smarter, then those who receive it should have to wait until their efforts pay off in higher corporate earnings and stock prices rather than expecting to gain right away from buybacks that increase EPS by simply reducing the number of shares outstanding. Moreover, research has shown that even at high-tech companies that have broad-based stock-based compensation programs, resulting in high levels of dilution, the volume of shares repurchased tends to be a multiple of the volume of shares that employees receive from options and awards. ${ }^{32}$

The only logical explanation for the prevalence of buybacks is that stock-based pay gives executives ample incentives to do them. ${ }^{33}$ How ample those incentives are depends in large part on a process of CEO-pay determination that produces a "ratchet effect" that, across booms and busts in the stock market, inflates the general level of CEO pay over time. Here is a five-step guide to how U.S. CEOs manage their way to higher executive pay:

1. The CEO appoints a compliant board of directors, with the most prominent and influential members being other CEOs who all have an interest in increasing the "benchmark" level of executive compensation. It has long been known that, whatever the formalities of the election of the directors of a U.S. corporation, it is the CEO who chooses its board members. ${ }^{34}$ A CEO does not want to be beholden to directors who fail to appreciate his or her talent to run the company. Occasionally, the disastrous performance of a company or a scandal might result in a previously compliant board ousting a CEO. Hedge-fund activists, eager to loot an established company, sometimes

\footnotetext{
30 Gene Smiley and Richard H. Keehn, "Margin Purchases, Brokers' Loans and the Bull Market of the Twenties." Business and Economic History. 2d series. 17, 1988: 129-142.

31 Lazonick, "Profits Without Prosperity," p. 51.

32 Lazonick, Sustainable Prosperity in the New Economy?, ch. 2

33 Lazonick, "Taking Stock."

34 See Jay W. Lorsch with Elizabeth MacIver, Pawns or Potentates: The Reality of Corporate Boards, Harvard Business School Press, 1989. For a recent discussion of CEO power vis-à-vis the board, and its decline in the face of hedge-fund activism and certain regulatory changes, see Marcel Kahan and Edward Rock, "Embattled CEOs," Texas Law Review, 88, 2010: 87-1051. This alleged decline in CEO power manifests itself in top executives becoming ever more committed to "maximizing shareholder value," which in turn gets translated into increases in their stock-based pay. The reason why the "hostile" takeovers that marked the late 1980s have largely disappeared is because there is no longer any hostility between what used to be called corporate raiders and top corporate executives. As I discuss below, both parties stand ready to disgorge cash to shareholders through stock buybacks and dividends. On the rise and dominance of shareholder value ideology and its implications for corporate resource allocation and executive pay, see William Lazonick, "Innovative Enterprise and Shareholder Value," Law and Financial Markets Review, 8, 1, 2014: 52-64.
} 
see fit, and garner the proxy votes, to oust the CEO. ${ }^{35}$ In general, however, when a board keeps a CEO and his or her top people in place, it marks its stamp of approval with generous compensation packages.

2. The CEO hires compensation consultants who benchmark the pay of other CEOs who hire the same group of consultants to benchmark the pay of other CEOs. It is the role of compensation consultants to justify the remuneration that the board deems CEOs (and their senior executive team) deserve. Consultants, hired by the CEO at the expense of the firm, collect data on the compensation of other CEOs of comparable firms. Then they recommend pay packages for the CEO for whom they are working and the members of his or her team of senior executives. Consultants will almost invariably recommend that "their" CEO be paid well above the median (the $75^{\text {th }}$ percentile is a common rating) of the other CEOs surveyed-a sign that their particular client is no ordinary executive. Over time, this benchmarking exercise inevitably ratchets up the pay of all CEOs. Given that CEOs are key members of each other's boards, they rarely (and probably never) complain that a fellow CEO is being overpaid. ${ }^{36}$

3. The CEO and his or her senior executive team get paid in a currency-the company's shares - that the board can dole out abundantly in stock options and stock awards, with increased numbers of shares included in new options and awards when stock prices fall, and also in many cases for hitting financial targets when existing stock awards vest, thus ratcheting up CEO pay when stock prices rise. Executives and their boards can further influence the potential gains from stock options by securing more favorable exercise prices by "repricing" or "backdating" options and by "spring-loading" (issuing options ahead of "good news") or "bullet-dodging" (issuing options after "bad news"). ${ }^{37}$ Unlike stock options, which have no value if the market price of the stock remains below the option exercise price, stock awards always have some value because they are bestowed on the executive at no cost. It is often the case, however, that stock awards only vest if the company's stock price or earnings per share reaches a stipulated level. More generally, the higher the price of a company's stock-even if it turns out to be a temporary spike-the more both options and awards can contribute to ratcheting up executive pay.

4. The CEO and other high-level executives potentially benefit from SEC Rule 10b-18 that, as we have seen, permits a corporation to give manipulative boosts to its stock price through large-scale open-market stock repurchases. In the early 1980s, the corporatefinance debate among academics, regulators, and executives was about how much dividends a company could distribute to shareholders while retaining sufficient

\footnotetext{
35 For the case of hedge-fund activist Nelson Peltz's takeover of DuPont, see Alana Semuels, “Can America's companies survive America's most aggressive investors?" The Atlantic, November 18 2016, at http://www.theatlantic.com/business/archive/2016/11/activist-investors/506330/

${ }^{36}$ See Graef S. Crystal, In Search of Excess: The Overcompensation of the American Executive, Norton, 1991; Lucian Bebchuk and Jesse Fried, Pay Without Performance: The Unfulfilled Promise of Executive Compensation, Harvard University Press, 2004; Roger L. Martin, Fixing the Game: Bubbles, Crashes, and What Capitalism Can Learn from the NFL, Harvard Business Review Press, 2011; Mihir Desai, "The Incentive Bubble," Harvard Business Review, March 2012: 124-133; Rana Foroohar, "Why Warren Buffett should vote 'no' on Coke," Time, April 24, 2014; Joe Nocera, "Buffett punts on pay," The New York Times, April 25, 2014.

37 See Hopkins and Lazonick, "The Mismeasure of Mammon," pp. 16-17.
} 
earnings to invest in the company's productive capabilities. ${ }^{38}$ Since then, however, encouraged by the regulatory authority, buybacks have become not only enormous but also pervasive. According to the consulting company FactSet, from the second half of 2011 through the first half of 2016, with the stock market booming, between 360 and 390 of the companies in the S\&P 500 Index did stock buybacks in any particular quarter. ${ }^{39}$ Companies deploy buybacks in a competition to boost their stock prices, and the winnings from the competition show up in the stock-based pay that corporate executives take home.

5. The CEO and his or her senior executive team potentially benefit from the SEC's reinterpretation in 1991 of Section 16(b) of the Securities Exchange Act that enables top executives as insiders to profit from the immediate sale of stock acquired through exercising stock options rather than having to wait six months as had been the case since 1934. Reflecting its permissive attitude to stock buybacks from 1982, through the 1991 reinterpretation the SEC made it much easier for top executives who are privy to the company's repurchasing activity to use this insider information to time their option exercises and stock sales to increase their pay. Until 1991, Section 16(b) of the 1934 Securities Exchange Act prevented top executives from reaping short-swing profits when they exercised their stock options. Under Section 16(b), if an insider sold shares acquired by exercising stock options within six months of the exercise date, the gains had to be forfeited to the corporation. In 1991, by arguing that a stock option is a derivative, the SEC determined that henceforth the six-month waiting period would begin at the option's grant date, not the exercise date. Since the option grant date is always at least one year before the option exercise date, this reinterpretation of Section 16(b) meant that top executives, as company insiders, could now sell the shares acquired from stock options immediately upon exercise. ${ }^{40}$

The result has been an ongoing explosion of executive pay since the 1980s, enabling senior executives to be well represented among the top one-tenth of one percent of households in the U.S. income distribution. Figure 6 displays data for 1916 to 2011 on the income shares of the top $0.1 \%$ of U.S. households, collected from tax returns by Thomas Piketty, Emmanuel Saez, and their colleagues. ${ }^{41}$ As can be seen, the largest component of executive pay over the past quarter century has been "salaries," supplemented by spikes in capital gains at the peaks of the stock-market booms in 2000 and 2007. The "salaries" data, which also display spikes in stock-market booms, include substantial stock-based pay taxed at

38 See, for example, the final speech of Harold Williams as chairman of the SEC before resigning his position in view of the election of Ronald Reagan to the U.S. Presidency. Harold M. Williams, "The Corporation as Continuing Enterprise," address delivered to the Securities Regulation Institute, San Diego, California, January 21, 1981, at www.sec.gov/news/speech/1981/012281williams.pdf. Williams had previously been a corporate lawyer, business executive, and dean of the UCLA business school.

${ }^{39}$ Andrew Birstingl, "FactSet Buyback Quarterly," September 20, 2016, at

http://www.factset.com/websitefiles/PDFs/buyback/buyback_9.20.16

40 Carole Gould, "Shaking up executive compensation," The New York Times, April 9, 1989, p. F13; Jan M. Rosen, "New regulations on stock options," The New York Times, April 27, 1991, p. 38.

41 "The World Wealth and Income Database: http://topincomes.parisschoolofeconomics.eu/\#Database: United States, Top $0.1 \%$ income composition. 
ordinary rates, which is not distinguished as stock based in the data collected from personal income-tax returns. ${ }^{42}$

Federal tax returns include information on a filer's occupation and, through an employer identification number (EIN) on Form W-2, the type of business sector that provides the taxpayer with his or her primary employment income. Jon Bakija, Adam Cole and Bradley Heim accessed federal tax return data for selected years from 1979 to 2005 to analyze the occupations of federal taxpayers at the top of the U.S. income distribution. They found that "executives, managers, supervisors, and financial professionals account for about 60 percent of the top $0.1 \%$ of income earners in recent years, and can account for 70 percent of the increase in the share of national income going to the top $0.1 \%$ of the income distribution between 1979 and 2005."43

Figure 6. Share of total U.S. incomes of the top 0.1\% of households in the U.S.
income distribution and its components, 1916-2011

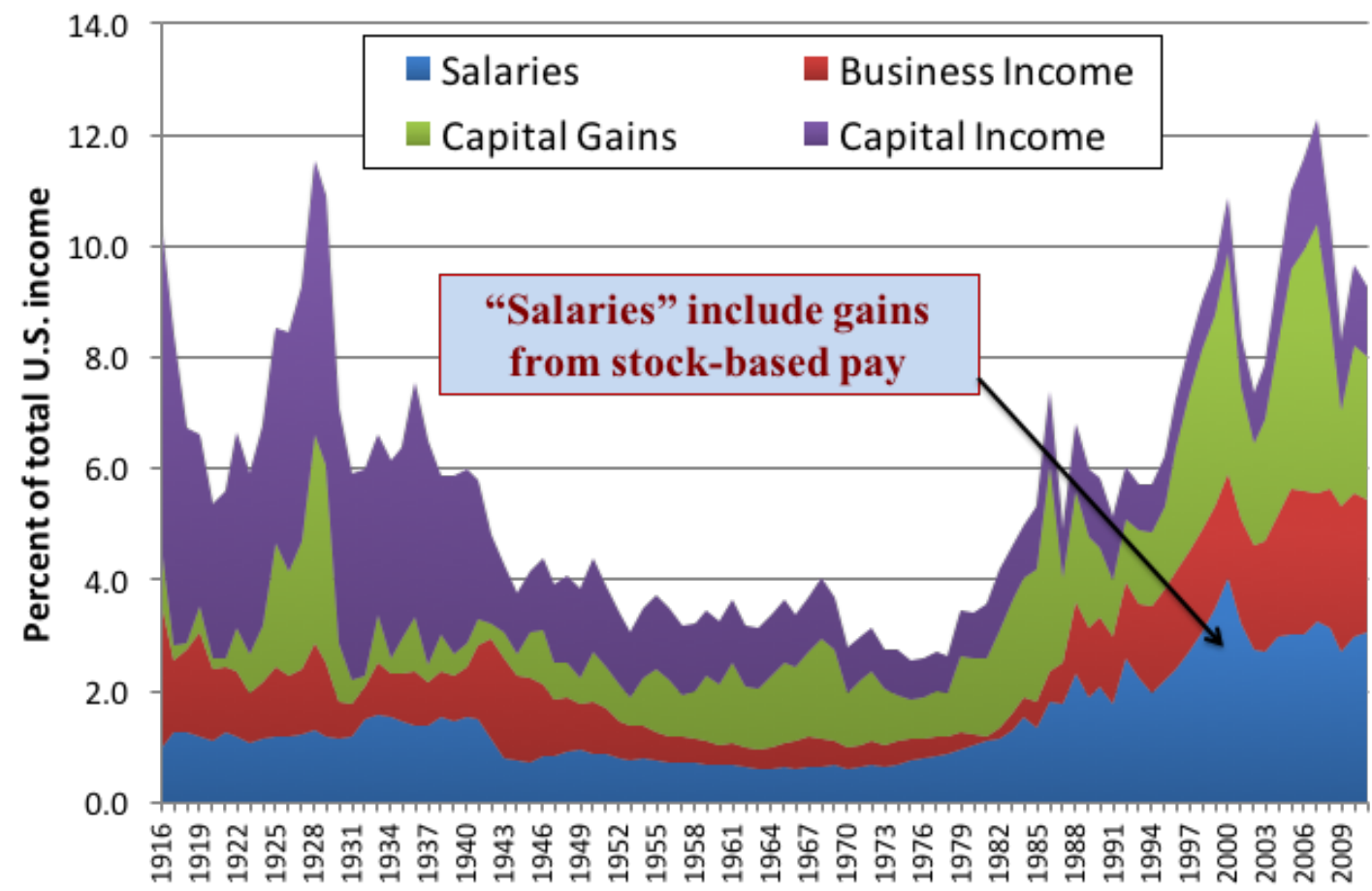

Source: http://topincomes.parisschoolofeconomics.eu/\#Database: United States, Top 0.1\% income composition.

Note: The category "salaries" includes compensation from the realized gains on exercising stock options and the vesting of stock awards.

42 Almost all gains from exercising employee stock options and the vesting of employee stock awards are taxed at the ordinary income-tax rate, not at the capital-gains tax rate, with taxes withheld by the employer at the time that options are exercised or awards vest. Hence these stock-based gains are reported as part of "wages, tips, other compensation." IRS Form 1040 for individual income-tax returns has the line item (no. 7): "Wages, salaries, tips, etc. Attach Form(s) W2," in which realized gains from stock-based pay are included but not shown separately from other forms of compensation. On Form W-2, the corresponding item is (no. 1) "Wages, tips, other compensation."

43 Jon Bakija, Adam Cole, and Bradley T. Heim, "Jobs and Income Growth of Top Earners and the Causes of Changing Income Inequality: Evidence from U.S. Tax Return Data," working paper, April, 2012, at https://web.williams.edu/Economics/wp/BakijaColeHeimJobsIncomeGrowthTopEarners.pdf. The quote is from the paper's abstract. 
For 2005, they found that, of taxpayers whose incomes (including capital gains) placed them in the top $0.1 \%$, executives, managers, and supervisors in non-finance businesses made up 41.3 percent of the total, while financial professionals (including management) were another 17.7 percent. Of the 41.3 percent who were non-finance executives, managers or supervisors, 19.8 percent were salaried and the rest were in closely held businesses. ${ }^{44}$ Besides the 6.2 percent of the top $0.1 \%$ who were "not working or deceased," the next largest occupational groups were lawyers with 5.8 percent, real estate with 5.1 percent, and medical with 4.1 percent.

We can use the Standard \& Poor's ExecuComp database, which compiles data on executive pay that is in SEC Form DEF 14A-the proxy statement that a company files prior to its annual general meeting of shareholders-to get an idea of the representation of high-paid corporate executives among the top $0.1 \%$ of households in the income distribution. In 2012, for example, the threshold income including capital gains for inclusion in the top $0.1 \%$ of the income distribution was $\$ 1,906,047.45$ From the ExecuComp proxy statement data on "named" top executives (the CEO, CFO, and three other highest-paid executives), in 2012, 4,339 executives (41 percent of the executives in the ExecuComp database that year) had total compensation greater than this threshold amount, with an average income of $\$ 7,524,168$. Of that amount, 64 percent were realized gains from stock-based compensation, with 32 percent derived from the exercise of stock options and the other 32 percent from the vesting of stock awards.

The number of corporate executives who, in 2012, were members of the top $0.1 \%$ club was, however, far higher than 4,339 for two reasons. First, total corporate compensation of the named executives does not include other non-compensation income (from securities, property, fees for sitting on the boards of other corporations, etc.) that would be included in their federal tax returns. If we assume that named executives whose corporate compensation was below the $\$ 1.91$ million threshold were able to augment that income by 25 percent (to pick a plausible number) from other sources, then the number of named executives in the top $0.1 \%$ in 2012 would have been 5,095.

Second, included in the top $0.1 \%$ of the U.S. income distribution were a potentially large, but unknown, number of U.S. corporate executives whose pay was above the $\$ 1.91$ million threshold, but who were not named in proxy statements because they were not the CEO, CFO or one of the three other executives named by their particular companies in proxy statements. For example, of the highest paid IBM executives in 2012 named in the company's proxy statement, the lowest paid had a total compensation of $\$ 9,177,663$. There were presumably many other IBM executives whose total compensation was between this amount and the $\$ 1.91$ million threshold for inclusion in the top $0.1 \%$. These "unnamed" executives would have been among the top $0.1 \%$ in the income distribution.

Therefore, top executives of U.S. business corporations-industrial as well as financialare very well represented among the top $0.1 \%$ of the U.S. income distribution, with much, and often most, of their compensation income coming from the realized gains from

\footnotetext{
44 Ibid., p. 38.

45 The World Wealth and Income Database, at http://topincomes.parisschoolofeconomics.eu/\#Database: United States, P99.9 income threshold.
} 
exercising stock options and the vesting of stock awards. When this mode of compensating top executives is combined with the fact that Wall Street has, since the 1980s, judged the performance of corporations by their quarterly stock prices, the importance of stock-based pay in executive compensation is clear. Stock-based pay gives top executives powerful personal incentives to boost, from quarter to quarter, the stock prices of the companies that employ them. In stock buybacks, these executives have found a potent, and SECapproved, instrument for stock-market manipulation from which they can personally benefit, even if the stock-price boosts are only temporary.

The ExecuComp database provides the numbers needed to determine how much money the highest-paid corporate executives in the United States take home in total and the proportion of their total compensation which is stock based. Figure 7 shows the average total compensation of the 500 highest-paid executives in the ExecuComp database for each year from 2006 through 2015. It ranges from a low of $\$ 15.9$ million in 2009 , when the stock markets had crashed, with stock-based pay (realized gains from stock options and stock awards) making up 60 percent of the total, to a high of \$32.6 million in 2015, with stockbased gains making up 82 percent of the total. U.S. corporate executives are incentivized to boost their companies' stock prices and are amply rewarded for doing so. In SEC-approved stock buybacks, they have at their disposal an instrument to enrich themselves. In their massive, widespread, and ubiquitous use of this instrument, they have been participating in the looting of the U.S. business corporation.

Figure 7: Average total compensation and cumulative percentage shares of pay components, 500 highest-paid executives in each year, 2006-2015

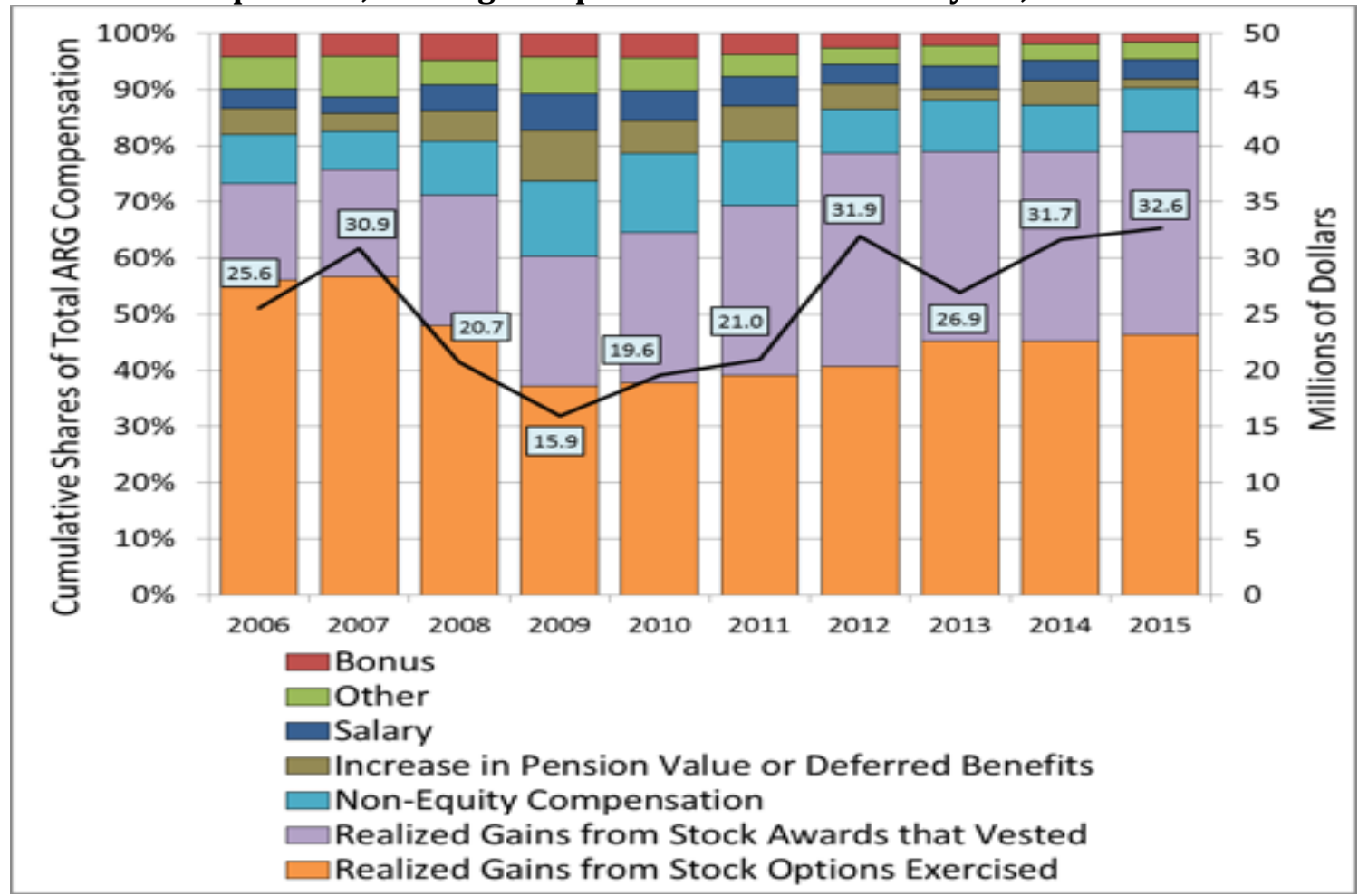

Source: Standard \& Poor's ExecuComp database, retrieved October 11, 2016. Calculations by Matt Hopkins of the Academic-Industry Research Network 
Note: The following extraordinarily highly paid outliers, with $\$ 1$ billion or more in total compensation, have been removed: 2012, Richard Kinder, Kinder Morgan, $\$ 1.1$ billion, and Mark Zuckerberg, Facebook, $\$ 2.3$ billion; 2013, Mark Zuckerberg, \$3.3 billion.

\section{How, and Why, the Value-Extracting CEO Undermines Innovative Enterprise}

Do buybacks affect the capability of the companies that do them to innovate and compete? The answer to this question requires detailed research into companies and industries to discern the impacts of a company's financial behavior on the three social conditions of innovative enterprise-strategic control, organizational integration, and financial commitment-and then relate these effects on innovative capabilities to competitive outcomes. One problem inherent in doing this type of research is that, like the innovation process itself, the deleterious impacts of buybacks on that process only unfold and become apparent over time. In generating competitive products, the three conditions of innovative enterprise are dynamically interrelated, a process that can only be understood through an in-depth longitudinal case study approach. ${ }^{46}$ Through this type of research into the social dynamics of innovative enterprise, we have gained a number of important insights that enable us to pose hypotheses into how stock buybacks can undermine a company's innovative capabilities.

\section{a) Strategic control}

Senior executives who are willing to waste hundreds of millions or billions of dollars annually on buybacks are likely to lose the judgmental capacity to comprehend the types of investments in organization and technology that are required to remain innovative in their industries. Executives' use of financial tools to determine whether the "relevant cost of capital"(as Jensen put it in an essay on "agency costs"47) justifies investment in innovation reflects, in my view, this loss of judgmental capacity. ${ }^{48}$ Instead, the current structure of stock-based executive remuneration creates incentives for senior executives to allocate resources in ways that achieve "timely" boosts to stock prices that help to increase their take-home pay. ${ }^{49}$ There are other ways in which, depending on the industry in which the company operates, an executive can generate manipulative increases in stock prices; a prominent example is price-gouging in the pharmaceutical industry. ${ }^{50}$ More generally,

\footnotetext{
46 For references to the body of empirical research that has been carried out from the "innovative enterprise" perspective, see Lazonick, "Labor in the Twenty-First Century"; Matt Hopkins and William Lazonick, "Who Invests in the High-Tech Knowledge Base?" Institute for New Economic Thinking Working Group on the Political Economy of Distribution Working Paper No. 6, September 2014 (revised December 2014), at https://ineteconomics.org/ideas-papers/researchpapers/who-invests-in-the-high-tech-knowledge-base; William Lazonick, Philip Moss, Hal Salzman, and Öner Tulum "Skill Development and Sustainable Prosperity: Collective and Cumulative Careers versus Skill-Biased Technical Change," Institute for New Economic Thinking Working Group on the Political Economy of Distribution Working Paper No. 7, December 2014, at https://ineteconomics.org/ideas-papers/research-papers/skill-development-andsustainable-prosperity-cumulative-and-collective-careers-versus-skill-biased-technical-change; Hopkins and Lazonick, "The Mismeasure of Mammon."

47 Michael C. Jensen, “Agency Costs of Free Cash Flow, Corporate Finance, and Takeovers," American Economic Review, 76, 2, 1986: 323-329.

48 See Carliss Y. Baldwin, "How Capital Budgeting Deters Innovation - and What To Do About It," Research Technology Management, 34, 6, 1991: 39-45; Clayton Christensen, Stephen P. Kaufman, Willy C. Shih, "Innovation Killers: How Financial Tools Destroy Your Capacity to Do New Things," Harvard Business Review, January 2008: 98-105.

49 Lazonick, "Taking Stock."

50 Lazonick et al., "U.S. Pharma’s Business Model.”
} 
however, the stock buyback is a powerful tool at the disposal of corporate executives for manipulating the stock market for their personal gain.

\section{b) Organizational integration}

Collective and cumulative, or organizational, learning about the technologies, markets, and competitors relevant to a particular industry is the foundation for generating the higher quality, lower cost goods and services that result in productivity growth. ${ }^{51}$ Productivity is collective because one learns through the interaction with others in a hierarchical and functional division of labor. Productivity is cumulative because what the collectivity learns today provides the foundation for what it is capable of learning tomorrow. What I call "collective and cumulative careers" are essential for organizational learning, especially in industries that are technologically and organizationally complex. It is on the basis of higher levels of productivity generated by organizational learning that business enterprises can pay their valued employees higher wages on a sustainable basis. Organizational learning in turn depends on a "retain-and-reinvest" corporate resource-allocation regime in which senior executives make corporate resource-allocation decisions that, by retaining people and profits in the company, permit reinvestment in the productive capabilities that can generate competitive (high-quality, low-cost) products. ${ }^{52}$ Our research into the dynamics of innovative enterprise supports the hypothesis that, as part of a corporate resourceallocation regime that downsizes the U.S. labor force and distributes corporate cash to shareholders, stock buybacks are done at the expense of investments in collective and cumulative careers. The disappearance of this career employment in major business enterprises is central to the erosion of the American "middle class" over the past three decades. ${ }^{53}$

\section{c) Financial commitment}

Buybacks represent a withdrawal of internally controlled finance that could be used to support investment in the company's productive capabilities. For many of the largest repurchasers, such as the four high-tech companies included in Table 1 above, dominant product-market positions based on past investments in innovation generate the stream of profits that enable these companies to do billions of dollars in buybacks year after year without running low on cash. The ability of some companies to use their cash reserves, often leveraged by borrowed funds, to manipulate their stock prices places pressures to do large-scale buybacks on other companies whose "success" is measured by stock-price performance but whose cash flow is insufficient to support their buyback habits. Every once in a while, as documented in our research, a company that has done massive buybacks over a period of years hits a financial wall, at which point the billions of dollars that it

\footnotetext{
51 Lazonick, "The Theory of Innovative Enterprise”; Lazonick et al., "Skill Development and Sustainable Prosperity.”

52 William Lazonick and Mary 0'Sullivan, "Maximizing Shareholder Value: A New Ideology for Corporate Governance," Economy and Society, 29, 1, 2000: 13-35; Lazonick, "Stock Buybacks.

53 Lazonick, "Labor in the Twenty-First Century": William Lazonick, Philip Moss, and Joshua Weitz, "The Equal Employment Opportunity Omission," Institute for New Economic Thinking Working Paper No. 53, December 5, 2016, at https://www.ineteconomics.org/research/research-papers/the-equal-employment-opportunity-omission.
} 
wasted on buybacks are not available to support a process to restructure its accumulated capabilities to become innovative once again. ${ }^{54}$

If stock buybacks undermine innovative enterprise, why does the U.S. government permit them? The answer is the dominance of a flawed economic theory that argues that MSV, implemented in part through buybacks, leads to superior economic performance. Corporate executives, with their stock-based incentives, have embraced the ideology of the economic superiority of MSV, justifying this mode of "returning" value to shareholderseven though the executives should know that the vast majority of shareholders never actually invested in the productive capabilities that create value. For over 30 years, under the sway of MSV and with the acquiescence of senior corporate executives, the U.S. government agency that is supposed to regulate the stock markets "to protect investors, maintain fair, orderly, and efficient markets, and facilitate capital formation," 55 has had Rule 10b-18 in effect that encourages companies to do open-market repurchases to manipulate their stock prices.

Buybacks bear a considerable part of the responsibility for a damaged U.S. economy. This mode of resource allocation serves to concentrate income and wealth at the top of the distribution and comes at the expense of investment in the types of stable and remunerative career employment opportunities that can yield a broad-based middle class. When the most profitable corporations are in a downsize-and-distribute mode, sustainable prosperity - stable and equitable economic growth - in the U.S. economy becomes an impossible goal. 56

Underpinning the legitimacy of the buyback corporation is the MSV ideology that companies should be run to maximize the distribution of income to those participants in the corporate economy who matter least to its operation and performance. ${ }^{57}$ MSV ideology is rooted in two misconceptions of the role of public shareholders in the U.S. business corporation. The most fundamental error is the assumption that public shareholders invest in the productive assets of the corporation. That error is then compounded by the assumption that it is only public shareholders who make risky investments in the corporation's productive assets, and hence that it is only shareholders who have a claim on the corporation's profits. Once we recognize the flaws in these assumptions, the factual foundation for MSV ideology falls apart.

\footnotetext{
54 Lazonick, "Everyone is paying the price for share buy-backs"; Lazonick, "The buyback boondoggle"; William Lazonick, "The Financialization of the US Corporation: What Has Been Lost, and How It Can Be Regained" Seattle University Law Review 36, 2013: 857-908; Lazonick, "Labor in the Twenty-First Century."

55 U.S. Securities and Exchange Commission, "The Investor's Advocate: How the SEC Protects Investors, Maintains Market Integrity, and Facilitates Capital Formation," at http://www.sec.gov/about/whatwedo.shtml\#.VJN6FAlA.

56 Lazonick, "Labor in the Twenty-First Century."

57 Value extraction by those who have made no contributions to the process of value creation is most obvious in the case of hedge-fund activists who purchase blocks of a company's stock on the market, and then pressure executives to "unlock" value for shareholders. See, for example, our analysis of the role of the stock market in the history of Apple Inc. and the recent raids on Apple's corporate treasury by hedge fund activists David Einhorn and Carl Icahn. Lazonick et al, "Apple's Changing Business Model"; William Lazonick, "Numbers show Apple shareholders have already gotten plenty," Harvard Business Review Blog, October 16, 2014, at hbr.org/2014/10/numbers-show-apple-shareholders-havealready-gotten-plenty; William Lazonick, Matt Hopkins, and Ken Jacobson, "What we learn about inequality from Carl Icahn's $\$ 2$ billion 'no brainer,'” Institute for New Economic Thinking Ideas \& Papers, June 6, 2016, at https://ineteconomics.org/ideas-papers/blog/what-we-learn-about-inequality-from-carl-icahns-2-billion-apple-no$\underline{\text { brainer }}$
} 
The proponents of MSV argue that by making stock-based pay a major proportion of executive compensation, the incentives of corporate managers in the allocation of resources can be aligned with those of public shareholders. ${ }^{58}$ Only if the corporation's "free cash flow" is distributed (or as they put it, "disgorged") to shareholders, the MSV proponents contend, will the economy's resources be allocated to their most efficient uses. The money from the corporate coffers can be distributed to shareholders in the forms of cash dividends and stock repurchases. ${ }^{59}$

Central to the MSV argument is the assumption that, of all participants in the business corporation, shareholders are the only economic actors who make productive contributions without a guaranteed return. All other participants such as creditors, workers, suppliers, and distributors allegedly receive a market-determined price for the goods or services that they render to the corporation, and hence take no risk of whether the company makes or loses money. On this assumption, the very definition of "free cash flow" includes corporate earnings that under a retain-and-reinvest resource-allocation regime the corporation would have invested in training and retaining employees. And on this assumption, only shareholders have an economically justifiable claim to the "residual" of revenues over costs after the company has paid all other stakeholders their guaranteed contractual claims for their productive contributions to the firm.

By the MSV argument, shareholders are the only stakeholders who need to be incentivized to bear the risk of investing in productive resources that may result in superior economic performance. As the only "residual claimants," the MSV story goes, shareholders are the only stakeholders who have an interest in monitoring managers to ensure that they allocate resources efficiently. Furthermore, by buying and selling corporate shares on the stock market, public shareholders, it is argued, can directly reallocate resources to uses that are more efficient than investments within the corporation.

As already stated, there are two fundamental flaws with this argument. ${ }^{60}$ The first flaw is the contention that, via the stock market, public shareholders allocate resources to more efficient uses. As a general rule, they do not. Passive shareholders merely use the stock market to generate returns on their household savings to augment their incomes, often to fund their retirement. Most representative today of active shareholders are hedge-fund activists, formerly known as corporate raiders and better described as corporate predators, who seek to extract value from companies by pressuring CEOs and their boards to downsize and distribute, and where possible engage in price gouging of buyers, so that they can sell their shares at higher prices and thereby build their hedge-fund "war chests," thus increasing their financial power to extract even more value from companies as time goes on. ${ }^{61} \mathrm{MSV}$ is the ideology, now widely accepted by conservative and liberal economists alike, that legitimizes this looting of the industrial corporation.

58 See Michael C. Jensen and Kevin J. Murphy, "Performance Pay and Top Management Incentives" Journal of Political Economy, 98, 2, 1990: 225-264.

59 Jensen, "Agency Costs of Free Cash Flow."

60 See Lazonick and O'Sullivan, "Maximizing Shareholder Value"; William Lazonick, "Innovative Enterprise and Shareholder Value," Law and Financial Markets Review, 8, 1, 2014: 52-64; Lazonick, "Stock Buybacks."

61 As an example, see Lazonick, et al., "What we learn about inequality from Carl Icahn's $\$ 2$ billion 'no brainer'." See also Lazonick, et al., "U.S. Pharma's Business Model.” 
The second flaw with MSV lies in the erroneous assumption that shareholders are the only corporate participants who bear risk. Taxpayers through government agencies and workers through the firms that employ them make risky investments in productive capabilities on a regular basis. From this perspective, households as taxpayers and workers may have "residual claimant" status: that is, an economic claim on the distribution of profits.

Through government investments and subsidies, taxpayers regularly provide productive resources to companies without a guaranteed return. As an important example, but only one of many, the 2016 budget of the U.S. National Institutes of Health (NIH) is $\$ 32.3$ billion, with a total NIH investment in life-sciences research from 1938 through 2015 of \$958 billion in 2015 dollars. ${ }^{62}$ Businesses that make use of life-sciences research benefit from the public knowledge that the NIH generates. As risk bearers, taxpayers who fund such investments in the knowledge base, or physical infrastructure such as roads, have a claim on corporate profits if and when they are generated. Through the tax system, governments, representing households as taxpayers, seek to extract this return from corporations that reap the rewards of government spending. However, tax revenues on the prospective gains from innovation depend on the success of innovative enterprise while, through the political process, tax rates on those gains are subject to change. Hence, for both economic and political reasons, the returns to taxpayers whose money has been invested for the benefit of business enterprises are by no means guaranteed.

Workers regularly make productive contributions to the companies for which they work through the exercise of skill and effort beyond those levels required to lay claim to their current pay, but without guaranteed returns. ${ }^{63}$ Any employer who is seeking to generate a higher-quality, lower-cost product knows the profound productivity difference between employees who just punch the clock to get their daily pay and those who engage in learning to make productive contributions through which they can build their careers and thereby reap future returns in work and in retirement. Yet these careers and the returns that they can generate are not guaranteed, and under the downsize-and-distribute resourceallocation regime that MSV ideology has helped put in place these returns and careers have been, in fact, undermined.

As risk bearers, therefore, taxpayers whose money supports business enterprises and workers whose efforts generate productivity improvements have claims on corporate profits if and when they occur. MSV ignores the risk-reward relation for these two types of economic actors in the operation and performance of business corporations. Instead it erroneously assumes that shareholders are the only residual claimants.

The irony of MSV is that the public shareholders whom it holds up as the only risk bearers typically never invest in the value-creating capabilities of the company at all. Rather, they purchase outstanding corporate equities with the expectation that while they are holding the shares dividend income will be forthcoming and with the hope that when they decide to

\footnotetext{
${ }^{62}$ National Institutes of Health, "Budget," at http://www.nih.gov/about-nih/what-we-do/budget. See also Lazonick and Tulum, "US Biopharmaceutical Finance."

${ }^{63}$ Lazonick, Competitive Advantage on the Shop Floor; Lazonick, "The Theory of Innovative Enterprise."
} 
sell the shares the stock-market price will have risen to yield a capital gain. Following the directives of MSV, a prime way in which the executives who control corporate resource allocation fuel this hope is by allocating corporate cash to stock buybacks to pump up their company's stock price. Yet it is the senior executives themselves who are best positioned to gain from these manipulative price increases. Senior executives "disgorge" this cash flow, not for the sake of efficient resource allocation, but rather for the sake of increasing their own stock-based pay. ${ }^{64}$

\section{Reinstalling the Value-Creating CEO}

MSV is not simply a business ideology. It is a product of neoclassical economics which, in both its conservative and liberal versions, views the market as the mode of efficient resource allocation and ignores the central role of business corporations in the success or failure of the economy to invest in productive employment opportunities. ${ }^{65}$ In my view, MSV is the most economically damaging ideology ever propounded by the economics profession. Any policy agenda that is concerned with employment opportunity must engage in new economic thinking about the role of the corporation in the economy and take steps to put an end to the economic - and one might also add the political-disaster that MSV has wrought.

The deeper intellectual problem is that agency theory, like the neoclassical theory of the market economy from which it is derived, lacks a theory of innovative enterprise. For neoclassical economics, strategic control is irrelevant because only the possession of money matters in the investment process, as it flows from one profitable opportunity to another. But liquid money is a commodity that plays no role in generating the high-quality, low-cost products on which economic growth depends. The generation of these products depends on a combination of strategic control that allocates resources in the face of uncertainty, organizational integration that transforms technologies and accesses markets, and financial commitment that sustains the innovation process until it can generate returns. For agency theory, in sharp contrast, the innovative enterprise is a market imperfection from which, for the sake of superior economic performance, cash must be disgorged.

There is no doubt that at certain times and in certain places, with technologies, markets, and competitors undergoing change, a previously innovative enterprise can find it problematic to remain competitive. But MSV exploits and exacerbates the vulnerability of the corporation that seeks to reallocate its resources to make this productive transformation. Lacking a theory of innovative enterprise, agency theorists have no way of recognizing, let alone analyzing, the sources of a malfunctioning corporation or the strategic, organizational, and financial conditions needed to renovate it. Disgorging the cash flow to shareholders may in fact cause a business organization to fail, but even when it can be argued that massive distributions to shareholders is a response to corporate failure,

\footnotetext{
${ }^{64}$ Hopkins and Lazonick, "The Mismeasure of Mammon."

65 William Lazonick, "The Theory of the Market Economy and the Social Foundations of Innovative Enterprise," Economic and Industrial Democracy, 24, 1, 2003: 9-44; Lazonick, "Innovative Enterprise or Sweatshop Economics?"
} 
this flow of funds does not fix that failure. Rather it contributes to an inequitable income distribution and an eroding middle class.

From the perspective of innovation theory, the MSV-driven policy prescriptions of agency theory are precisely the economic institutions that must be undone. For starters, the SEC, as the regulator of the stock market, should recognize its mistake in the adoption of Rule $10 \mathrm{~b}-18$, and ban open-market repurchases. Then policy reform should be focused on the disincentives to invest in innovation created by the current system of executive stockbased pay, with a new system seeking to ensure that the remuneration of senior executives depends on the innovative success of the business organization as a whole.

Once the problems of strategic control have been addressed, the process of taking back the corporation can turn to the critical role of organizational integration. Productivity in an advanced economy depends on the extent to which members of the labor force have the opportunity to engage in collective and cumulative learning over the course of careers that may span 40 years or more. Under what I have called the" Old Economy business model," major corporations supported this social condition through the norm of a career with one company, albeit almost exclusively for white males. It is unrealistic to assume that in a world of open-systems technologies and intense global competition the norm of a career with one company could, or should, be restored.

That does not, however, lessen the need for collective and cumulative careers as the employment foundation of a highly productive economy. It is reasonable to believe that in the provision of lifelong learning through on-the-job experience, government agencies and civil society organizations, including universities, will have to continue to play important, and perhaps even growing, roles in enabling individuals to pursue collective and cumulative careers. The business corporation, however, will have to anchor a national system of career employment with a retain-and-reinvest resource-allocation regime. Jettison the downsize-and-distribute ideology of MSV, and U.S. business corporations can focus on becoming learning organizations once again.

If hundreds of billions of dollars annually stop flowing out of the nation's major corporations to do buybacks, then vast amounts of resources will become available to provide the financial commitment that innovation requires. ${ }^{66}$ Ban buybacks and companies will be able to use these funds not only, or even primarily, to finance capital expenditures but more importantly to attract, train, retain, and motivate their career employees. In hightech companies a significant proportion of these employees will be engaged in R\&D, but the innovative enterprise needs experienced and motivated employees in a range of other functions as well. And some of funds made available by a buyback ban can flow to the government as tax revenues to enable it to invest in the physical infrastructure and human knowledge that can underpin the next generation of innovation.

The governance of innovative enterprise requires a dramatic change in the accepted purpose of the corporation and the composition of corporate boards. From the perspective

\footnotetext{
${ }^{66}$ See, for example, William Lazonick, "What Apple should do with its massive piles of money," Harvard Business Review Blog Network, October 20, 2014, at http://blogs.hbr.org/2014/10/what-apple-should-do-with-its-massive-piles-ofmoney/
} 
of innovative enterprise, the purpose of the business corporation is to produce high quality, low cost, i.e., competitive, goods and services. If the business corporation can perform this role, then profits will follow. The board of directors should be composed of people who have insights into how a company can generate competitive products, including representatives of workers and taxpayers who collectively invest in the innovation process. These board members should be capable of exercising sound judgment of the types of investment in productive capabilities that the company should make as well as the company's responsibilities to the society of which it is a part.

Replacing agency theory with its focus on "downsize-and-distribute" with innovation theory with its focus on "retain-and-reinvest" highlights, therefore, three institutional changes that are essential for reinstalling the value-creating CEO:

Ban stock buybacks: Households as savers who allocate some of their assets to corporate stocks can get an income from dividends if and when a retain-and-reinvest company can afford to pay them, and then, as a result of well-managed investments in productive capabilities, expect to be able to sell shares at higher prices if and when they want to readjust their financial portfolios. Stock buybacks that are permitted, and indeed encouraged, by the SEC under Rule 10b-18 are simply a means of manipulating stock prices to reward those who are positioned to time their share selling, including the senior corporate executives who make the buyback decisions, hedge-fund managers who apply pressure for buybacks, and investment bankers who help engineer them. Stock buybacks make a mockery of the SEC's stated mission "to protect investors; maintain fair, orderly, and efficient markets; and facilitate capital formation."67 SEC Rule 10b-18 should be rescinded, and stock buybacks should be banned.

Restructure corporate executive incentives: The vast majority of the pay of senior corporate executives is stock based, rewarding them for selling corporate shares in the wake of rapid stock-price increases, often assisted by buybacks and other forms of market manipulation. The stock prices of publicly listed companies are driven by a combination of innovation, speculation, and manipulation, and increasingly executives have been rewarded for value-extracting manipulation rather than value-creating innovation. Reward senior executives for generating high-quality products at low unit costs (the economic definition of innovation that results in competitive goods and services), and tie their remuneration to the increased employment stability and enhanced earnings of the broad base of employees whose skills and efforts help to generate those products. As a first step in this process, the SEC needs to ensure that the public knows how much corporate executives actually get paid. As Matt Hopkins and I have shown, the SEC has promulgated what are called "estimated fair value" measures of stock-based executive pay that significantly, and often dramatically, understate executives' actual realized gains from stock-based pay because the estimation formulae (Black-Scholes-Merton pricing models in the case of stock options) fail to capture the roles of innovation, speculation, and manipulation in driving stock prices. ${ }^{68}$

\footnotetext{
67 U.S. Securities and Exchange Commission website, at https://www.sec.gov/about.shtml.

${ }^{68}$ Hopkins and Lazonick, "The Mismeasure of Mammon"; Hopkins and Lazonick, "Corporate executives are making way more money than anyone reports." For example, in 2015 for the 500 highest-paid executives, total compensation including actual realized gains from stock-based pay averaged \$32.6 million, with 82 percent from stock-based pay,
} 
Transform corporate governance: Through government investment in physical infrastructure and the society's knowledge base, households-as-taxpayers risk their money in helping to fund business investment in productive capabilities. Through the application of their skills and efforts, households-as-workers risk their time, and hence livelihoods, in helping to generate competitive products that may result in future business profits. On these bases, households-as-taxpayers and households-as-workers should have representation on the boards of directors of publicly listed companies. Households-asshareholders should also have board representation, but it should be as savers. They do not generally invest in the productive capabilities of the companies whose shares they hold, and hence should not be called "investors," as is typically the case. Parties who have actually invested in a company's productive capabilities should have board representation. But speculators and manipulators who make their money by buying and selling corporate shares, and hence do not make productive investments and would be in positions to abuse insider information, should not be permitted to be on corporate boards. And by that criterion, CEOs who sit on corporate boards and control corporate resource allocation should be innovators who create value through a regime of retain-and-reinvest, not manipulators who extract value through a regime of downsize-and-distribute.

whereas their total compensation using estimated fair value measures averaged $\$ 17.1$ million, with the fair-value estimates making stock-based pay 62 percent of the total. 